\title{
Personality Change: Implications for Organizational
} Behavior

\begin{tabular}{|r|l|}
\hline Journal: & Academy of Management Annals \\
\hline Manuscript ID & ANNALS-2016-0008.R4 \\
\hline Document Type: & Article \\
\hline Keywords: & PERSONALITY, ORGANIZATIONAL BEHAVIOR, PSYCHOLOGY \\
\hline \multicolumn{2}{|c}{} \\
\hline
\end{tabular}

SCHOLARONE $^{\text {m }}$
Manuscripts 


\title{
PERSONALITY CHANGE:
}

IMPLICATIONS FOR ORGANIZATIONAL BEHAVIOR

\author{
Stefano Tasselli \\ Rotterdam School of Management, Erasmus University \\ Burgemeester Oudlaan 50, 3062 PA Rotterdam, The Netherlands \\ tasselli@,rsm.nl
}

Martin Kilduff

UCL School of Management, University College London

1 Canada Square, E14 5AA London, United Kingdom

m.kilduff@ucl.ac.uk

Blaine Landis

UCL School of Management, University College London

1 Canada Square, E14 5AA London, United Kingdom

b.landis@ucl.ac.uk

In press in the Academy of Management Annals

\begin{abstract}
Acknowledgments: We thank Matthew Cronin and Daan van Knippenberg for their editorial guidance, and two anonymous reviewers for their suggestions. The paper benefited from comments from reading groups and discussions at the UCL School of Management; and Rotterdam School of Management, Erasmus University.
\end{abstract}




\title{
PERSONALITY CHANGE:
}

\section{IMPLICATIONS FOR ORGANIZATIONAL BEHAVIOR}

\begin{abstract}
:
The paper focuses on an emergent debate in organizational behavior concerning personality stability and change. We introduce foundational psychological research concerning whether individual personality, in terms of traits, needs, and personal constructs, is fixed or changeable. Based on this background, we review recent research evidence on the antecedents and outcomes associated with personality change. We build on this review of personality change to introduce new directions for personality research in organizational behavior. Specifically, we discuss how a view of personality as changeable contributes to key topics for organizational behavior research, and how this new approach can help broaden and deepen the scope of personality theory and measurement. The study of personality change offers a range of new ideas and research opportunities for the study of organizational behavior.
\end{abstract}

\section{KEYWORDS:}

Personality Change; Personality Stability; Traits; Needs; Personal Constructs; Self-Development; Organizational Events; External Events; Outcomes of Personality Change; Organizational Research. 
We live in an age in which people plan, pursue, and experience individual changes that affect career and life trajectories. People improve their educational credentials, change residences, move jobs, switch nationalities, and undergo gender reassignment. All of this is familiar to organizational researchers. But evidence and theory concerning personality change are only just emerging in the organizational behavior research landscape, despite personality psychology findings (see Roberts, Walton, \& Viechtbauer, 2006, for a meta-analysis), practitioner attention (e.g., Alicke \& Sedikides, 2011), and mass media interest (e.g., Soto, 2016). Organizational research (e.g., Dalal, Meyer, Bradshaw, Green, Kelly, \& Zhu, 2015; Li, Barrick, Zimmerman, \& Chiaburu, 2014) emphasizes the stability of personality (e.g., McCrae \& Costa, 2003, 2008) rather than change of personality. There has been neglect of the possibility that personality can change, and neglect of when and how such changes occur.

The view of personality as a stable aspect of the individual self has contributed greatly to the understanding of human behavior in organizations (Roberts, Kuncel, Shiner, Caspi, \& Goldberg, 2007). Personality, as a stable set of traits, represents a core construct, as discussed in numerous reviews (e.g., Schmitt, 2014), special issues (e.g., Casciaro, Barsade, Edmondson, Gibson, Krackhardt, \& Labianca, 2015), and chapters in almost every organizational behavior textbook (e.g., Robbins \& Judge, 2017). Stability in personality matters for organizations because it helps us understand people's behavior in many work-related domains, including employee performance (Grant \& Parker, 2009; Harrison, Newman, \& Roth, 2006; Organ, Podsakoff, \& Podsakoff, 2010; Parker \& Collins, 2010), social networks (e.g., Feiler \& Kleinbaum, 2015; Klein, Lim, Saltz, \& Mayer, 2004; Landis, 2016), employee withdrawal (Sackett, 2002; Zimmermann, 2008), and employee retention (Li, Fay, Frese, Harms, \& Gao, 
2014). In all of this research, there has been an explicit or implicit emphasis on the stability of personality.

A view of personality as changeable challenges current perspectives in organizational behavior. For researchers, treating personality as changeable allows consideration of the effects of self-development, organizational events, and external events and processes on individuals' work-related dispositions (e.g., Boyce, Wood, Daly, \& Sedikides, 2015). In place of an exclusive focus on personality as a fixed attribute of individuals, researchers can consider personality change as a dependent variable. Personality can be considered as a set of attributes that can be modified by events and processes. An emphasis on changeable personality has implications for numerous areas of inquiry, including leadership (e.g., Balkundi, Kilduff, \& Harrison, 2011), personality-fit research (e.g., Schneider, Smith, Taylor, \& Fleenor, 1998), task design (e.g., LodiSmith \& Roberts, 2007), personnel selection and development (e.g., Harms, Spain, \& Hannah, 2011), and job performance (e.g., Deinert, Homan, Boer, Voelpel, \& Gutermann, 2015). Even modest changes in personality traits can result in "profound" consequences for individuals (Roberts, Wood, \& Caspi, 2008: 383). For consumers of organizational behavior research, such as students and managers, treating personal characteristics as changeable promotes a developmental mindset linked to resilience, low stress, and achievement (e.g., Yeager \& Dweck, 2012).

Personality change in organizational behavior has been neglected, in part, because researchers have tended to render such change "impossible by definition" (Gendlin, 1964: 101). Research on the Big Five personality taxonomy (neuroticism, extraversion, openness to experience, agreeableness, and conscientiousness) characterizes these traits as "the basic dispositions that ... endure through adulthood" (McCrae \& Costa, 2003: 3). Similarly, in 
organizational behavior research, the emphasis on the stability of personality is relatively ubiquitous. Thus, a recent review states that personality traits "reflect an individual's enduring patterns of cognition, motivation, and behavior exhibited across contexts" (Li, Fay, Frese, Harms, \& Gao, 2014).

In our review, we balance this emphasis on personality stability with a review of ideas and evidence concerning personality change. We draw from the debate in organization and management research contrasting stability and change. This debate permeates management research at the macro level (e.g., organizational ecology vs. strategic choice) and at the organizational level, where identity is either seen as enduring (e.g., Albert \& Whetten, 1985) or identity is seen as emergent (e.g., Gioia, Schultz, \& Corley, 2000). At the level of individual persons, organizational behavior scholars have reacted to the critiques of personality research from psychologists (e.g., Mischel, 1973, 2004) and organizational researchers (e.g., Davis-Blake \& Pfeffer, 1989; Salancik \& Pfeffer, 1978) by championing the stability over time of personality and related constructs (e.g., Gerhart, 2005; Staw, Bell, \& Clausen, 1986). The time is ripe for a consideration of the other side of the coin - theory and evidence concerning personality change.

There are many different approaches to personality. The list incorporates traits (e.g., Allport, 1937; Barrick \& Mount, 1991), biology (e.g., Dabbs, Hargrove, \& Heusel, 1996), psychoanalysis (e.g., Baumeister, Dale, \& Sommer, 1998), humanistic approaches (e.g., Maslow, 1954; Rogers, 1947, 2012), motivation (e.g., McClelland, 1965), social learning (e.g., Rotter, 1954), and cognitive approaches (e.g., Kelly, 1955; Mischel, 1973), among others. We adopt a contemporary theorist's definition that captures the whole spectrum of the person's individuality rather than just one slice of personality theory and research: "Personality refers to an individual's characteristic pattern of thought, emotion, and behavior, together with the psychological 
mechanisms - hidden or not - behind these patterns" (Funder, 1997: 1-2). Thus, personality

change refers to change in the individual's characteristic pattern of thought, emotion, or behavior as well as change to the mechanisms behind these patterns.

This review includes empirical, conceptual, meta-analytic, and review papers published between 2006 and 2017 from journals in management, sociology, psychology, and related fields. We searched for relevant articles using combinations of the following search terms: personality change/personality dynamics/psychological change. We concentrated our search on journals regarded as primary outlets in their field, and we also included specialist journals as appropriate. Because this is the first paper concerning personality change in relation to organizational behavior, we also delved into prior research to provide context for contemporary developments. We have striven to bring a comprehensive perspective to bear on what has been a muchneglected research arena. We necessarily draw heavily from personality psychology research given the paucity of work in organizational behavior that considers personality change.

We structure the review in three major sections. First, we present a brief history of personality change theory and research. Second, we review the antecedents of personality change in terms of self-development, organizational events and processes, and external events and processes that impinge on organizational careers. Third, we articulate an overarching framework that can guide future research.

\section{Brief History}

There has long been interest in the question of whether individuals are fixed or changeable in their dispositions. Theory and evidence can be adduced to favor one or the other perspective. As David McClelland was moved to comment on the stark divide in personality research on the topic of personality change: "A man from Mars might be led to believe that 
personality change appears to be very difficult for those who think it is very difficult, if not impossible, and much easier for those who think it can be done" (McClelland, 1965: 322). As with people in general (Dweck, 1999, 2008), personality theories differ as to whether they view personality change as integral to human beings (e.g., personal construct theory - Kelly, 1955) or whether they view personality as consisting of relatively stable entities (e.g., the Big Five trait approach) (Pervin, 1994). On the side of the stability of personality, the theory of humors, according to which people's temperaments are rooted in their physiology, dates back to ancient Greece, but has continued to fascinate researchers throughout history and continues to play a role in contemporary research on personality stability (e.g., Rothbart, Ahadi, \& Evans, 2000). On the side of personality change, there is an equally distinguished lineage, deriving from the theory of Heraclitus concerning how people, influenced by the river of life, are constantly in the flux of change (Sabelli \& Carlson-Sabelli, 1989). And people have been depicted as mutating toward one of many selves depending on the character of the groups to which they address themselves (e.g., James, 1890; Roberts \& Donahue, 1994).

In the modern era, scholarly interest in personality change is evident in theories that gained traction in the 1950s and 1960s. Unlike the work of early theorists, such as Freud and Jung, who emphasized the continuing influence of childhood on adult personality, the writings of Gordon Allport (1937, 1961), David McClelland (1965), and George Kelly (1955) emphasized personality change throughout adulthood. This emphasis on personality change contributed to debates concerning the relative stability of adult personality (e.g., the person-situation debate initiated by Mischel, 1979), and contributed to the search for evidence of trait heritability (e.g., Jang, McCrae, Angleitner, Riemann, \& Livesley, 1998). The focus of research moved away from prior emphases on personality as changeable. 
Leaving aside individual abilities such as IQ as unrelated to our current focus on dispositional rather than ability-based individual differences, and building on the definition of personality introduced above (Funder, 1997), personality research in organizational behavior can be organized into three main types of approaches (Roberts \& Wood, 2006). The first approach includes the traits that describe people's patterns of thoughts, feelings and behaviors (e.g., Funder, 1991); the second includes the motives and values that capture people's desires and needs (e.g., Hogan, 1982; McClelland, 1965; Murray, 1938); and the third refers to personal constructs, schemas, scripts, and stories that people develop in order to make sense of and anticipate experience (e.g., Kelly, 1955; McAdams, 1993).

Traits. In looking at the development of trait approaches, it is striking that Gordon Allport, who is often identified as the progenitor of a list of personality trait terms that helped form the basis of Big Five research (e.g., Allport \& Odbert, 1936), noted that people changed in response to their social environments. Indeed, in both his early and later writings, he dismissed the notion of a fixed personality trait: "The ever-changing nature of traits and their close dependence upon the fluid conditions of the environment forbid a conception that is over-rigid or over-simple" (Allport, 1937: 312). Allport embraced the notion of personality flexibility: "The pull of the situation is, however, so powerful that we are forced to regard personality as never a fixed entity or pattern" (Allport, 1961: 181). Although he claimed that strong situational pressures might change traits, Allport also suggested that people have an inherent drive toward psychological growth. He argued that this drive helps account for most personality development (Allport, 1961). Thus, for Allport, personality development could be said to occur naturally through a process of inner psychological growth and maturation (Zuroff, 1986). Despite the 
general emphasis in contemporary personality theory on the fixity of traits, there is now considerable interest in trait change (e.g., Boyce et al., 2015; Roberts et al., 2008).

Motives, needs, and values. From the perspective of motives, needs, and values, a distinctive perspective that recognizes the malleability of human personality specifically in relation to organizational behavior is acquired needs theory (McClelland, 1965; see Winter, 2011, for a recent empirical test). McClelland emphasized ways in which people who set goals to strengthen one or more motives could realign their personality system through the practice of relevant behaviors including workplace activities. (This focus on behavior-induced personality change has received recent validation - see, for example, Magidson, Roberts, ColladoRodriguez, \& Lejuez, 2014). Undeterred by prevailing ideas concerning the stability of personality, McClelland derived inspiration from psychotherapists in developing short (one-tothree week) courses that enabled many people to change the achievement aspects of their personalities - aspects important for careers in sales and entrepreneurship (e.g., McClelland, 1987; see Collins, Hanges, \& Locke, 2004 for a meta-analysis).

Perhaps the most influential current approach to personality from a needs perspective is the emphasis on two primary motivations: the need for status and the need for belonging. People strive for status, personal achievement, and power but they also strive for social acceptance, inclusion, and the avoidance of rejection (Baumeister \& Leary, 1995; Hogan, 1996; Hogan \& Holland, 2003; Mitchell, 1997). Status striving and communion striving represent energy resources (Hobfoll, 1989) that people devote to getting ahead of others and getting along with others (Halbesleben \& Bowler, 2007). Status and communion are fundamental motivational orientations (Wiggins, 1991) of particular relevance for organizational behavior (Stewart \& Barrick, 2004). 
Personal constructs, schemas, scripts, and stories. Personality approaches that focus on traits or needs tend to compare across individuals. But such normative approaches often miss the distinctive idiosyncrasies of individuals. Capturing individual distinctiveness requires more idiographic approaches such as those offered by researchers who collect people's life narratives (e.g., Block \& Airasian, 1971; McAdams, 1993) or personal projects (e.g., Little, 1983). We focus here on George Kelly's (1955) personal construct approach that is explicit in its endorsement of personality change at the individual level, but that also offers a generalizable theory and method for comparing across individual construals. Kelly (1955) offered organizational behavior researchers (e.g., de Vries, Walter, Van der Vegt, \& Essens, 2014; see Cornelius, 2015, for a review) a personality psychology that emphasizes the principle of constructive alternativism as a way to understand and potentially change the idiosyncratic cognitive systems people use to manage problems. According to personal construct theory, each person evolves through experience in the world a set of schematic templates for anticipating their own and others' behaviors. These personal construct systems help frame and simplify events and allow predictions about what is likely to happen (e.g., Borman, 1987). The principle of constructive alternativism states that the individual's current set of interpretations (that form the basis of the individual's personality) are always subject to revision or replacement: "No one needs to paint himself into a corner; no one needs to be completely hemmed in by circumstances; no one needs to be the victim of his biography" (Kelly, 1955: 15). People can improve their ways of dealing with the world by learning from their mistakes and thereby revising the basic constructs through which they view the world and their experiences of it.

Personality, from this perspective, does not represent some fundamental essence of the individual but rather a system of construing by which the individual relates to others - a system 
that functions much like a set of hypotheses derived from the individual's theory of the self. Of course, given the importance of this construing system to the individual, attempts at personality change are likely to face resistance. But Kelly emphasized that personality is alterable, in the same way that a flawed scientific theory is alterable in the face of failed hypotheses. The distinctive approach to individuals' personality change embodied in personal construct theory continues to influence both psychological research (see Walker \& Winter, 2007, for a review), research across the social sciences more generally (see the recent handbook edited by Winter \& Reed, 2015), and decision-making research in organizations (e.g., Eden \& Ackermann, 2010).

Kelly's approach to personality change focused on individualized role therapy during which clients enacted hypothetical characters in order to derive evidence for how they could engage in new ways of behaving and thinking. Thus, people were considered active agents in the construction of their own sense-making personas rather than reactive victims of inherited traits or environmental demands (see Neimeyer, 1993, for a review). Building on the argument of personal construct theory that a person's processes are psychologically channeled by the ways in which he or she anticipates events (Kelly, 1963), recent studies show that people can constructively change their personality through intensive coaching, self-expression, and experiential knowledge (e.g., Weiss, Bates, \& Luciano, 2008). And constructive personality change has been widely used in leadership training in industry and in coaching programs during organizational change (e.g., Reger, Gustafson, Demarie, \& Mullane, 1994). Personality theory, building on Kelly's (1955) emphasis on the importance of understanding cognitive-affective encodings, expectancies, and beliefs, emphasizes the distinctive nature of individual personality signatures in the context of situational variability (Mischel \& Shoda, 1995). 
Thus, several theorists in the post-war era depicted people as active agents who were able to adapt their personalities in response to challenges and opportunities. This research was based on a developmental view of personality that emphasized ways in which people could change. But personality research as a whole tended to rely on assumptions concerning the stability of fixed traits. In consequence, one of George Kelly's students, Walter Mischel (1968), fired the first salvo in what came to be known as the person-situation debate when he critiqued the fixed trait approach to personality as inconsistent with evidence that people's behaviors tended to be determined by the pressures of different situations. The reaction in personality psychology was to redouble efforts to find personality stability (e.g., Bem \& Allen, 1974; Epstein \& O’Brien, 1985). Thus, one resolution to the person-situation debate is to acknowledge that a person's momentary behaviors vary widely due to situational pressures, but that a person's average scores on personality traits over longer stretches of time are "very stable" (Fleeson, 2004: 86). In organizational behavior, much effort was devoted to providing evidence of stability in people's dispositions over their working lives (e.g., Bell \& Staw, 1989; Staw et al., 1986; Staw \& Ross, 1985). The situational side of the argument was quick to assert the importance of job design and other situational contributors to variability (e.g., Gerhart, 1987), and to attack the resurgence of personality research as flawed given that organizations represented strong situations in which dispositional effects could be dismissed as “just a mirage” (Davis-Blake \& Pfeffer, 1989).

In recent decades, the field of organizational behavior has moved on from this personsituation debate. While acknowledging the relevance of situational pressures, researchers have demonstrated the importance of relatively fixed traits in predicting a range of outcomes of interest to organizational behavior that include performance motivation (see Judge \& Ilies, 2002, for a meta-analysis) and leadership (see Judge, Bono, Ilies, \& Gerhardt, 2002, for a meta- 
analysis). The situation in which the individual is embedded and the personality resources that the individual brings to bear on the situation are both now recognized as contributing to outcomes (e.g., Tasselli \& Kilduff, 2017). For example, recent research showed that Big Five personality traits were stronger predictors of job performance for jobs that were weakly constrained by situational pressures (e.g., jobs that were unstructured, and jobs in which employees had discretion to make decisions) relative to jobs that were strongly constrained (Judge \& Zapata, 2015). Moving on from the person-situation debate, our aim is to consider the evidence and implications for an organizational view of personality that incorporates the neglected developmental and change perspectives. Figure 1 (adapted from the neo-socioanalytic model of Roberts \& Nickel, 2017) represents a summary of antecedents to change, a typology of personality approaches, and likely outcomes of personality change.

Insert Figure 1 about here

\section{ANTECEDENTS OF PERSONALITY CHANGE}

Personality can change because of self-driven or external processes. We review research of relevance for organizational behavior concerning the antecedents of personality change. Specifically, we introduce and discuss recent research on self-development, organizational events and processes, and external events and processes.

\section{Self-Development}

The desire to change personality is widespread, with over $87 \%$ of people reporting that they want to change core aspects of the self that include extraversion and conscientiousness (Hudson \& Fraley, 2016). People in organizations tend to believe that they can change almost 
any work-relevant characteristic through effort (Maurer \& Lippstreu, 2008). And young adults self-report changes in industriousness, impulse control, and reliability even though outside observers fail to notice these changes (Jackson et al., 2009). In changing personality, selfaffirmation interventions, therapy, and self-actualization efforts enable individuals to develop more expansive views of the self, its relationships with the environment, and its resources (e.g., Cohen \& Garcia, 2008; Garcia \& Cohen, 2013; Hudson \& Fraley, 2015; Wilson, 2011; Yeager \& Walton, 2011).

Self-affirmation. In contrast to the traditional pessimism concerning person-driven change (e.g., Costa \& McCrae, 1988), recent studies show that self-affirmation activities, including writing about core personal values, can help shape individuals' personalities, both encouraging individuals to appraise life and work threats in a positive, non-defensive way and shaping people's psychological self-appraisals (e.g., Dweck, 2008; McQueen \& Klein, 2006). Through self-affirmation interventions, individuals reinforce their psychological self-integrity by manifesting and re-affirming values of importance for them (Garcia \& Cohen, 2013; Wilson, 2011; Yeager \& Walton, 2011). Changing personality, in these instances, relates to the ways in which people construe themselves and the psychological resources they have available to deal with challenges to their identities. Practices such as writing about core values can permanently change how people filter information about themselves and their environments (see Cohen \& Sherman, 2014, for a review).

Individuals can achieve change as they become self-affirmed and as others in the work environment affirm their new selves through positive feedback. Self-help, support groups, personal growth, and self-affirmation facilitate positive change in individual personality (e.g., Walker \& Winter, 2007). For people suffering from personality disorders related to depression 
and anxiety (emotions often experienced in the workplace - e.g., Kouchaki \& Desai, 2015; Priesemuth \& Taylor, 2016), guided self-help is effective in fostering positive change (see Cuijpers, Donker, van Straten, Li, \& Andersson, 2010, for a meta-analysis). And as people move into new roles in organizations, they experiment with provisional selves that serve as trials for possible but not yet fully elaborated professional identities (Ibarra, 1999) that can incorporate personality traits activated by the new work contexts (e.g., Judge \& Zapata, 2015).

In reviewing self-affirmation interventions and related approaches, it is worth noting that the prior advocates of personality change possibility were psychologists pursuing (non-Freudian) therapeutic approaches, particularly those associated with humanistic psychology, such as personal construct theory (Kelly, 1955), discussed above. A related modern-day approach is behavior activation (BA) therapy, in which individuals rate daily work activities on levels of importance and enjoyment, and then prepare a structured plan for engaging in activities consistent with their self-assessed important values (Farmer \& Chapman, 2016). Through increased engagement in activities that are considered important, enjoyable, and in accordance with individual values across numerous work and life-related domains, people can register increases in traits, such as conscientiousness, that relate to valued work outcomes (Magidson et al., 2014).

State or trait change? As extensive evidence has accumulated over the last decades on the possibility of personality change following individuals' self-development interventions (Rogers, 2007), two opposing perspectives have emerged concerning whether such personality changes capture state or trait variance. The first position argues that changes in personality observed during therapy are attributable to (relatively transient) state-level variance rather than (relatively enduring) trait-level variance (e.g., Du, Bakish, Ravindran, \& Hrdina, 2002). From this 
perspective, trait measures are imperfect constructs that capture both trait and state change. The second position claims that the changes observed during interventions may capture variation in the trait itself, and not in the state component of the personality construct (e.g., Soskin, Carl, Alpert, \& Fava, 2012). According to this second perspective, interventions enable enduring improvement to individuals' psychological disorders, and have real consequences for people's personal and work-related outcomes.

A recent meta-analysis (Roberts, Luo, Briley, Chow, Su, \& Hill, 2017) showed that personality changes following interventions involved trait (rather than state) variation. There was no evidence that the effects of interventions faded over time. Rather, the effects of interventions appeared to permanently affect people's personalities. The largest effect of such interventions on personality was observed for emotional stability and extraversion, whereas other traits, including openness to experience, did not evidence significant variation over time. Of note is that all forms of interventions (behavioral therapy, cognitive therapy, and psychodynamic interventions), with the exception of hospitalization, reported the same effects on personality change. These results concerning improvements in personality development are important given that, for example, people who exhibit stability or decreases in neuroticism over a period of 12 years have higher survival rates than people who exhibit increases in neuroticism over the same time interval (Mroczek \& Spiro, 2007).

Change efforts can be facilitated by relatively short-term interventions (e.g., Magidson et al., 2014; Smith, Glass, \& Miller, 1980) in contrast to the lifelong therapy advocated by Freudians and Jungians. For example, a 20-week cognitive-behavioral therapy intervention helped increase extraversion and decrease neuroticism (Clark et al., 2003). Therapies lasting four or more weeks achieved half the amount of change in personality traits that people usually 
display in their life course from young adulthood through middle age (half a standard deviation) (Roberts et al., 2017). Thus, a therapeutic endeavor to develop the work skills of those suffering drug dependencies involved clients in a six-week, five-days-a-week, six-hours-a-day program of vocational skill training and therapeutic engagement. The program succeeded in effecting positive change in personality traits of neuroticism, agreeableness, and conscientiousness. These changes were independent of symptom experience, demonstrating that shifts in adaptive orientation were not merely reflections of symptomatic relief: changes in personality scores were not acting simply as markers of shifts in state-level functioning. Instead, there was evidence of significant change in underlying traits (Piedmont, 2001).

The evidence suggests that people can change their personalities through processes that include personal striving, therapeutic engagement, active coaching, and reflective engagement with experiences at work. The positive message concerning personality change challenges the emphasis from much organizational psychology on the stability of individuals' dispositions over large chunks of their working life (e.g., Staw et al., 1986). People, of course, differ in the extent to which they have the motivation and ability to change their personalities, but these differences in the likelihood of personality change have been neglected in personality research (Mroczek, Almeida, Spiro, \& Pafford, 2006).

Self-actualization. These emphases on guided self-improvement and therapy toward a better, if not optimal, personality system have been taken up by researchers associated with the positive psychology movement, with a focus on how people can effect change toward sustainable happiness and well-being (Snyder \& Lopez, 2009). The emphasis in positive psychology is on the individual's self-actualization toward optimal well-being as exhibited in positive subjective 
experiences, positive personality traits, and the enactment of civic virtues (Seligman \& Csikszentmihalyi, 2000).

In advocating the possibility of change toward better functioning, the positive psychology perspective challenges the prevailing emphasis (e.g., McCrae \& Costa, 1994) on the relative stability of the Big Five personality factors. It also challenges the influential hedonic treadmill idea (e.g., Brickman \& Campbell, 1971) that the individual is likely to experience mild-tomoderate happiness fluctuations around a set point that stays relatively fixed. The positive psychology emphasis on optimizing human happiness through personality change is related to prior therapeutic theories and research in the domain of humanistic and constructivist psychology (e.g., Maslow, 1968) that similarly emphasized individuals' potential for radical change (Mahoney, 2002; Robbins, 2008). Positive psychology suggests people can effect permanent personality change through a set of behaviors that include: regular exercise, regular kindness to others, striving for important personal goals, effort toward meaningful causes, positive reframing of situations, reflections on one's own blessings, and the practice of classical virtues such as gratitude, hope, and forgiveness (Lyubomirsky, Sheldon, \& Schkade, 2005). In moving people toward greater happiness and well-being, these behaviors also decrease neuroticism and increase extraversion.

The theoretical framing of this positive psychology approach to personality change emphasizes a bottom-up process: Moment-to-moment fluctuations in personality can be targeted so that underlying traits themselves are gradually changed (Roberts et al., 2006). Healthy patterns of behavior are practiced until they become habitual. The repeated enactments of these positive behaviors then manifest themselves in trait-level change (Chapman, Hampson, \& Clarkin, 2014). This bottom-up process of personality change is particularly evident in the 
workplace, given the prevalence of work experiences in shaping how individuals think, feel, and behave (Wu, 2016). Indeed, research evidence is accumulating concerning how individuals can increase their positive affectivity and reduce negative traits (Jayawickreme \& Blackie, 2014). This evidence suggests that the repeated experience of frequent positive affect generates success across many different areas of individuals' lives (Lyubomirsky, King, \& Diener, 2005). People who change their personalities in ways that align with their goals experience increases in wellbeing over time (Hudson \& Fraley, 2016).

Thus, a major contribution of the positive psychology movement has been to counterbalance the emphasis on fixity of personality. According to positive psychology, the personality trait of positive affectivity is not highly constrained by either objective life conditions or genetic and biological factors. People are relatively free to increase their positive affectivity and to move closer toward their potential maximum (Watson, 2002).

The focus of positive psychology tends to be on doing rather than thinking or talking as a way to enact personality change (e.g., Watson, 2002). This emphasis on acting positively to achieve improvement has been criticized for offering simplistic answers to age-old questions concerning how to achieve happiness (Gable \& Haidt, 2005; Miller, 2008). But the positive psychology tent incorporates both action-oriented and cognitive-oriented research-based interventions. The cognitively oriented positive psychology researchers tend to be restrained in their claims concerning the magnitude of likely personality change. Can pessimists become optimists through change to the traits of neuroticism and extraversion? The answer, according to cognitive researchers, comes down to whether cognitive-behavioral therapies and efficacy training in problem-solving can effect permanent changes that result in behavior identical to that 
occurring among those natural optimists who are fortunate not to have to strive for such fundamental change (Carver \& Scheier, 2002).

Inspired by positive psychology ideas, the positive organizational behavior movement has emerged in the organizational research landscape and emphasizes the ways in which people within organizations can increase a range of outcomes, including confidence, self-efficacy, hope, optimism, subjective well-being, happiness, emotional intelligence, and resilience (e.g., Luthans, 2002; Youssef \& Luthans, 2007). New research in this domain investigates the ways people can flourish in the workplace via the positive work relationships they experience with colleagues and managers (e.g., Colbert, Bono, \& Purvanova, 2016).

\section{Organizational Events and Processes}

As suggested in Figure 1, personality change can also be triggered by organizational events and processes, including employment, organizational pressures, and interpersonal relationships with coworkers.

Employment and career development. Working is crucial to the identity and well-being of many people. Indeed, a two-year study of young people (aged 17-24 at the start of the study) showed that youth unemployment was associated with an increased risk of negative outcomes including personality dysfunction (Thern, de Munter, Hemmingsson, \& Rasmussen, 2017). After starting their first job, individuals tend to increase strongly in conscientiousness (Specht, Egloff, \& Schmukle, 2011) whereas people who become unemployed tend to experience decreases in agreeableness, conscientiousness, openness to experience (Boyce et al., 2015), and internal locus of control (Niess, 2014). Overall, unemployment is associated with a significant drop in life satisfaction (Lucas, Clark, Georgellis, \& Diener, 2004). Similarly, people who retire decrease strongly in conscientiousness (Specht et al., 2011). 
By contrast, people who increase their participation in the paid labor force and those who become more successful between the ages of 27 and 43 tend to become more assertive in their personalities (Roberts, 1997). There is, apparently, a surprising plasticity in individuals' personalities beyond the age of supposedly fixed dispositions. Work environments significantly influence patterns of personality change through processes that include occupational socialization (e.g., Stoll \& Trautwein, 2017; Wille \& De Fruyt, 2014). Other research has shown that work experiences for young adults (aged between 18 and 26) are predictive of changes in basic personality traits, although the evidence suggests co-development of personality and work experience rather than a simple causal effect (Roberts, Caspi, \& Moffitt, 2003). The results show the beneficial effects for young adults of gaining high-status jobs in terms of changing their personality toward lower scores on negative dimensions such as aggression, alienation, and stress, and toward higher scores on positive dimensions such as social closeness and well-being.

Considering the increasing emphasis in the modern business environment on the internationalization of work activities, it is notable that the personal jolt of experiencing even a temporary international work assignment affects personality. Early research on language and personality showed that the individual feels and behaves "like a different person" when speaking a second language (Guiora \& Acton, 1979). Both short-term and long-term international mobility change individuals' personalities (beyond self-selection explanations) toward greater openness to experience, agreeableness, and emotional stability (Zimmermann \& Neyer, 2013).

Organizational pressures. The constraints and stress that people experience within organizations can change personality, both for the better and the worse. For example, the severe psychological trauma that results from internment in a concentration camp induced depressive personality structures irrespective of pre-traumatic event life experiences (Fink, 2003). More 
generally, individuals facing temporary denial of individual freedom (such as imprisonment) are likely to develop antisocial personality problems (Lamb \& Weinberger, 1998). Organizations (such as asylums, prisons, and the military) that impose total control on individual expression and freedom can strip away the sense of self, resulting in changes to personality traits and functions (Goffman, 1961). And people who experience wrongful criminal convictions tend to exhibit "enduring personality change" including anxiety and post-traumatic stress disorder (Grounds, 2004).

Classic psychological research emphasized the positive effects of military training, suggesting that enrolment in the army matures young individuals and contributes to an improvement in socialization skills (James, 1910/1988). But more recent research challenged this positive view in investigating the complex patterns of personality change associated with a total organizational experience such as the military service. A study using a large longitudinal sample of German males showed that, in a two-year period, military recruits manifested a drop in their mean levels of agreeableness that persisted for five years even as they re-entered civilian life. Thus, extreme organizational pressures can entail long-lasting influences on personality (Jackson, Thoemmes, Jonkmann, Lüdtke, \& Trautwein, 2012; but see Schult \& Sparfeldt, 2015, for a contrasting perspective).

It is worthy of note that organizational roles that appear attractive and well-remunerated can leave a hidden legacy of psychological damage including personality deterioration. Players in the National Football League who experience concussions on the field of play are liable to a lifetime of depression (Didehbani, Cullum, Mansinghani, Conover, \& Hart, 2013). These routine head injuries do more than cause physical trauma - the effects on individuals' personality are 
also detrimental: self-reliance and increased irritability are evident to relatives within three months (Brooks \& McKinlay, 1983).

Organizational contexts can also change personality for the better. For example, as people move into more complex jobs, they tend to become more flexible, whereas moves into more autonomous jobs lead people to be more self-evaluative (Kohn \& Schooler, 1978) and more competent (Mortimer \& Lorence, 1979). Employees whose jobs require a variety of skills tend to experience higher well-being (Roberts et al., 2003), greater emotional stability (Brousseau \& Prince, 1981), and increased social dominance (Brousseau \& Prince, 1981). More generally, work autonomy tends to increase young adults' psychological well-being and positive emotionality (Roberts et al., 2003). Interestingly, work autonomy is also associated with an increase in young adults' psychological alienation (Roberts et al., 2003), suggesting that the rise in personal independence in modern work environments might hamper the quality of interpersonal interactions with coworkers. In contrast, stimulating work is associated with individuals experiencing higher well-being and higher psychological achievement (Roberts et al., 2003). A three-year longitudinal analysis showed that individuals stimulated by both higher job demands and job control were more likely to increase their proactive personality compared to people with less task control at work (Li, Barrick, Zimmerman, \& Chiaburu, 2014).

Thus, people look to organizational contexts for possibilities for personality renewal and affirmation (e.g., Roberts, Dutton, Spreitzer, Heaphy, \& Quinn, 2005). But people who select themselves into stressful work roles may experience unwelcome increases in neuroticism and decreases in extraversion $(\mathrm{Wu}, 2016)$. The inference is that high-status jobs and occupations are effective in promoting beneficial personality change, whereas stressful work roles can lead to unwanted personality change that depletes well-being. In general, if people in the workplace 
strive for daily shifts in thoughts, feelings, and behaviors, then they can expect these persistent state-level changes to eventually coalesce into changes in basic personality traits (Hudson \& Fraley, 2016).

Relationships with coworkers. The interpersonal context of work also contributes to personality change. Thus, the extent to which individuals experience relationships with coworkers as satisfactory relates to increased extraversion and decreased neuroticism (Scollon \& Diener, 2006). Students who perceive a better personal fit with the college environment and with their classmates are more likely to become open to experience and to gain higher academic achievements (Harms, Roberts, \& Winter, 2006). Individuals who increase their social investment in work activities with coworkers tend to become more conscientious and more agreeable, whereas people who de-invest in the social aspects of their work activities decrease in conscientiousness over time. Furthermore, people who increase their counterproductive behaviors toward colleagues (for example, making fun of people at work) also become less extraverted and less emotionally stable (Hudson \& Roberts, 2016).

Well-known research suggests that distinctive collegial contexts of organizations result from processes of attraction, selection, and retention of individuals who are similar in their personalities (e.g., Schneider et al., 1998). But evidence also suggests that contexts can grow more similar over time as people's personalities converge through contact with other people. In the workplace, common negative behaviors such as rudeness can spread as easily as the common cold with significant consequences for coworkers, including negative affect (Foulk, Woolum, \& Erez, 2016). And leader charisma can result via emotional contagion in followers imitating leaders' non-verbal behaviors, thereby enhancing the expression of followers' own charisma (Cherulnik, Donley, Wiewel, \& Miller, 2001). Beyond this, longitudinal research in the 
sociology of medicine shows widespread evidence of contagion among friends and friends of friends of loneliness, happiness, and depression that are related to the personality traits of neuroticism, positive affect, and negative affect (Cacioppo, Fowler, \& Christakis, 2009; Fowler \& Christakis, 2008; Rosenquist, Fowler, \& Christakis, 2011). Personality change may be speeded by the daily workplace encounters with others different from one's self.

\section{External Events and Processes}

Personality can change through individual desire, training, and agency, and through events and processes within work organizations. But work-related personality can also be shaped over time by the process of aging, as well as by individuals' experience of events that affect job experiences and careers. The Big Five, for example, can change following changes in interpersonal relationships (e.g., marriage), the death of a close person in the family (e.g., death of a parent), and changes in the composition of a family (e.g., birth of a child) (Roberts et al., 2006; Specht et al., 2011). Disruptive personal experiences such as alcohol abuse (e.g., Hicks, Durbin, Blonigen, Iacono, \& McGue, 2012; Littlefield, Sher, \& Wood, 2009) and personal trauma (e.g., Jayawickreme \& Blackie, 2014) contribute to changes in personality and have spillover effects in the workplace. Immigration, war, and other traumatic events can change personality too (Stewart \& Deaux, 2012). The appearance of relatively unchanging personality may depend on the consistency of situations to which the individual is exposed (Mischel, 1973; Roberts \& Wood, 2006). In this review, we focus on the effects on personality change of domestic jolts, education, and the aging process.

Domestic jolts. People experience changes in their lives due to domestic influences that may be invisible to work colleagues but that affect their personalities inside the workplace. Thus, a study over four years of nearly 15,000 people (mean age at start of study $=47$ ) showed that 
women who moved out of their parents' home (relative to women who remained) became more emotionally stable (although there was no effect for men - Specht et al., 2011). A six-year study of over 4,000 young adults (mean age at start of the research $=19.6$ ) showed that living with a partner (rather than by oneself or with one's parents) was associated with development in selfesteem (Wagner, Lüdtke, Jonkmann, \& Trautwein, 2013). An eight-year study of over 300 young adults (mean age at start of study $=24$ ) showed that the transition to living with a partner also led to decreases in neuroticism and increases in extraversion (Neyer \& Lehnart, 2007). And individuals who continued to cohabit with a partner tended to exhibit decreases in neuroticism and increases in agreeableness compared to those who ended these relationships (Lehnart \& Neyer, 2006). Self-ratings show that in the two years after getting married people become more agreeable, more conscientious, and less neurotic (Watson \& Humrichouse, 2006).

Childbearing is also associated with personality dynamics. A nine-year study of over 1,500 people of child-bearing age showed that the birth of a child tended to increase parents' emotionality, particularly for people with high baseline emotionality who already had two or more children. For men, having a child enhanced sociability, but only for men with high baseline sociability to begin with; for those with low baseline sociability, the arrival of a child decreased sociability (Jokela, Kivimäki, Elovainio, \& Keltikangas-Järvinen, 2009).

Overall, therefore, these domestic changes in people's lives can change personality traits such as conscientiousness and extraversion that have significant implications for people's success in organizational careers.

Education. The importance of educational paths and other formative activities has attracted the longstanding attention of organizational researchers (e.g., Judge, Cable, Boudreau, \& Bretz, 1995). But only recently has research investigated whether education affects 
personality-related skills, competences, and goals (e.g., Bandura, 1999). Students who attend class and spend more time on their homework than their peers tend to increase more in conscientiousness; similarly, students who experience fewer stressful experiences during their educational years are more likely to decrease in neuroticism (Jackson, 2011).

Some of the changes associated with education represent unanticipated consequences of personal choices. Specifically, college students who choose vocational specializations at university, as well as young professionals who choose vocational training at work, are more likely to exhibit increases in conscientiousness and agreeableness than their less vocationallyminded peers over a four-year interval (Lüdtke, Roberts, Trautwein, \& Nagy, 2011). The important question remains as to whether personality change results from inherent latent traits that lead students to choose a particular educational trajectory or whether the educational training itself, through knowledge and social skill acquisition, shapes personality.

Aging. From the very beginnings of psychology, leading voices proclaimed personality changes over the life course to be unlikely if not impossible. According to some influential researchers, the individual's personality is largely stable by the age of 30 (e.g., Costa \& McCrae, 1998; James, 1890). Others have claimed that personality is fixed much earlier - by adolescence (Bloom, 1964), or even by the age of two or three because of child-rearing practices (e.g., Sapir, 1934), or fully developed in terms of the ego, the id, and the superego by the age of five (e.g., Freud, 1923). In keeping with this traditional unwillingness to acknowledge the possibility of personality change over the life course, more recent theorists and empiricists have reiterated the mantra that the individual's personality is stable over time. Personality stability, we have been told, derives from the potency of inherited predispositions (e.g., Johnson, McGue, \& Krueger, 2005; Lykken \& Tellegen, 1996) or because of the influences of both genetics and environmental 
shaping (e.g., Cloninger, 1986). A weaker version of the stability argument is that personality change can happen later in life, but the probability of change decreases with age (Glenn, 1980).

Recent results challenge this stability perspective, showing that people experience substantial change in personality as a result of aging: Individuals tend to become more conscientious, more extraverted, and less neurotic over time (Roberts et al., 2006). Most personality change occurs between the ages of 20 and 40 (an important period in many adults' working lives), but people keep changing into middle and old age (Edmonds, Jackson, Fayard, \& Roberts, 2008; Roberts \& Mroczek, 2008). Older people, in particular, tend to exhibit increases in agreeableness and decreases in openness to experience and social vitality compared to the young and middle aged (Roberts et al., 2006). Moreover, conscientiousness and agreeableness continue to increase throughout early and middle adulthood at varying rates, whereas neuroticism tends to decline among women but not among men (Srivastava, John, Gosling, \& Potter, 2003). The cumulative amount of change of such trait domains across the life course exceeds one full standard deviation (Roberts \& Mroczek, 2008).

Cohort studies examine longitudinal change in personality by following the same group of individuals over time. A recent study of a Scottish cohort over a 63-year time interval (first assessment of personality at age 14 and second assessment at age 77) showed that the lifelong stability of personality was quite low, but that some aspects of personality in older age did relate to personality in childhood (Harris, Brett, Johnson, \& Deary, 2016). A study following a cohort of Hawaiians over a 40-year time interval found no to little evidence for stability in neuroticism and agreeableness, and modest to moderate evidence for stability in openness to experience, conscientiousness, and extraversion (Hampson \& Goldberg, 2006). Similarly, a longitudinal study tracking Harvard graduates over a 45-year time interval found modest correlations between 
the two time intervals for neuroticism and extraversion, and a moderate correlation for openness to experience (Soldz \& Vaillant, 1999).

Accidents, addictions, and other traumatic life events can accelerate the negative effects of aging on personality in ways that alter career possibilities. Despite the strong norms that separate home life and work life, recent research has argued that "organizations need to understand, acknowledge, and address the emotional upheaval, stress, and fear that their employees may experience as a consequence of events and crises outside the workplace" (Ragins, Lyness, Williams, \& Winkel, 2014: 765). For example, significant proportions of working adults engage in excessive alcohol consumption (e.g., Cahalan, Cisin, \& Crossley, 1969) and are employed until the middle or late stages of their disorder (Trice, 1962). This is a workplace problem to the extent that it affects performance and relationships in the workplace. Because of the spillover effects of addiction, there is widespread provision of employer-funded intervention programs (Webb, Skakeshaft, Sanson-Fisher, \& Havard, 2009). Alcohol addiction affects not just the physical health of employees, it also damages work-related personality traits leading to increases in neuroticism, impulsivity (Littlefield et al., 2009), and other personality dysfunctions (Hicks et al., 2012).

Physical activity (on or off the job) helps prevent such maladaptive psychological changes in adulthood and old age. More physically active individuals exhibit less decrease in extraversion, conscientiousness, agreeableness, and emotional stability as they age. Moreover, these individuals are also more likely to maintain psychological consistency over time (Stephan, Sutin, \& Terracciano, 2014, 2015).

Several trends emerge from these studies of age-related personality change and stability. Of note is the tendency for people to retain personality changes that occurred due to aging 
instead of returning to their earlier selves. There appears to be no biological set point where people change but then revert to earlier trait levels (Roberts \& Mroczek, 2008). Second, psychological functioning is not fixed at a certain age: Individuals retain the possibility of personality change throughout the life course, including middle and old age, challenging the assumption that personality is set "like plaster" by the age of 30 (James, 1890). Moreover, when people's personalities change due to aging (in the absence of problems related to trauma and addiction), these changes tend to be for the better. Compared to when they were young, individuals in their middle or old age tend to become more emotionally stable, agreeable, and self-confident, showing an overall increase in social maturity (Roberts \& Mroczek, 2008).

\section{OUTCOMES OF PERSONALITY CHANGE}

The current research literature suggests that personalities can and do change through processes and events that include self-development efforts (Hudson \& Fraley, 2017), experiences within organizations, and processes outside of the workplace (as summarized in the left part of Figure 1). As people's personalities change, there are likely to be changes in organizationally relevant outcomes, including how they construct themselves in terms of career choices, job roles, competencies, and other outcomes that we consider under the broad rubric of work-related identity. Personality change is also likely to shift how people are evaluated by others in their organizations in terms of their performance at work, their citizenship contributions, and their potential as leaders - outcomes that we consider under the broad rubric of work-related reputation. We highlight the possibilities of identity and reputation change (as summarized in the right part of Figure 1) but, due to the paucity of studies within organizational behavior, the aim of this brief and somewhat speculative section is to promote further research on how personality change affects identity and reputational outcomes. 


\section{Identity Change}

Personality change can have profound effects on workplace identity, which represents the way in which people define themselves in the context of organizational life (e.g., Pratt, Rockmann, \& Kaufmann, 2006). As personality changes, people are likely to change how they filter information about themselves and their environments (Cohen \& Sherman, 2014), thus leading them to see themselves differently. For example, people are likely to update their interaction strategies so that they seek out and interact with those who validate and reinforce their new, most current self-perceptions (e.g., Ibarra, 1999), given that people prefer to interact with those who see them as they see themselves (Swann \& Read, 1981).

Personality change at work is, therefore, likely to affect identity through the social network roles that people enact in organizations; but personality change also relates to formal work roles. As people become more or less extraverted, conscientious, and agreeable, these changes are likely to facilitate transitions into new work roles with consequences for changes to work identities (e.g., Hall, 1995). People who become absorbed in new work roles undergo identity change (e.g., West, Nicholson, \& Arnold, 1987).

Influential research also suggests that personality change affects individuals' identities in terms of their career preferences (e.g., Roberts et al., 2003). For example, changes in extraversion are related to the extent to which people experience changes in "presenter" career roles at work - these require individuals to shape ideas, images, or products in ways that make them more attractive and convincing (Wille, Beyers, \& De Fruyt, 2012). Increases in emotional stability result in individuals seeking out more secure and predictable work environments, just as increases in openness to experience result in individuals avoiding inflexible, conforming work environments (e.g., Wille \& De Fruyt, 2014). 
Overall, therefore, people who experience personality change are likely to have different experiences with which to construct their identities at work (e.g., Dickie, 2003). Work becomes meaningful to the individual when the individual's preferred self finds expression in work roles and in organizational membership (Kahn, 1990). Professionals and others who experience mismatch between their current identities and their work roles are likely to engage in identity customization processes, including deepening their work identities, creating new composite identities, and reverting to prior identities as temporary exigencies to manage role pressures (Pratt et al., 2006).

\section{Reputation Change}

As personality change affects identity change, and as people consequently enact different behaviors over time, people's reputations in the eyes of others are also likely to change. By reputation we refer to how others regard individuals on the basis of their past activities (including performance) at work (e.g., Ertug \& Castellucci, 2013). Personality change is likely to affect important reputation outcomes such as the ability to adapt to changing work circumstances (Huang, Ryan, Zabel, \& Palmer, 2014). The Big Five personality traits are well-known predictors of work performance (e.g., Barrick \& Mount, 1991), so individuals who exhibit change on these indicators are likely to exhibit change in how their contributions are perceived in the workplace. And, to the extent that individuals become more or less extraverted, agreeable, open, conscientious, and emotionally stable, they are likely to be seen differently by others as their interactions in the workplace undergo transformation (e.g., Ibarra, 1999).

Personality affects who seeks advice from whom, who becomes friends with whom, and even the people one names as a work partner (Fang, Landis, Zhang, Anderson, Shaw, \& Kilduff, 2015; Tasselli, Kilduff, \& Menges, 2015). Thus, changes to individuals' personalities are likely 
to change individuals' patterns of social connections. To the extent that people are known by the company they keep (e.g., Kilduff, Crossland, Tsai, \& Bowers, 2016), changes to interaction patterns mean changes to reputation in terms of how people are perceived by others. Network connections are prisms through which other people attempt to discern the individual's inner qualities, including performance potential (Podolny, 2001) and potential for conflicts in their relationships (e.g., Bolger \& Zuckerman, 1995).

The effects of personality change on reputation outcomes may generalize to whole cohorts of people entering employment at the same time and moving through socialization experiences. (For a review of cohort differences in personality, see Hülür, 2017). Personality effects are shaped by the time periods in which people live. Thus, in China, shyness went from being a desirable trait in traditional Chinese society to being an undesirable trait in the market economy era, with changing reputational consequences: Whereas in the earlier period shyness predicted leadership and achievement, in the market era, shyness predicted peer disregard and loneliness (Liu, Chen, Li, \& French, 2012).

Personality differences affect many reputational outcomes such as job performance (e.g., Barrick \& Mount, 1991; Hogan \& Holland, 2003), leadership (Bono \& Judge, 2004; Judge et al., 2002a), satisfaction (Judge, Heller, \& Mount, 2002b), citizenship behaviors (Borman, Penner, Allen, \& Motowidlo, 2001; Organ \& Ryan, 1995), and counterproductive work behaviors (Berry, Ones, \& Sackett, 2007). The big gap in our understanding concerns how personality change affects these reputational outcomes. The right-hand side of Figure 1 offers the most opportunities for new research activities. Beyond this general observation, we offer below more specifics on some new directions for research on personality change in organizations. 


\section{NEW DIRECTIONS FOR PERSONALITY RESEARCH IN ORGANIZATIONAL BEHAVIOR}

The growing evidence concerning personality change offers a rich set of opportunities for organizational behavior researchers to build on and challenge existing work. We envisage a shift away from personality traits as "uncovered factors which we formulate in terms of static explanatory contents" (Gendlin, 1964) toward more dynamic approaches involving personal flexibility and change. In this section, we explore whether and how a dynamic perspective on personality can contribute to reconsidering our understanding of central topics in organizational behavior research, including leadership emergence and leaders' behavior, personality-job fit, task design, and personnel selection. We suggest that this view of personality as changing over time can help broaden and deepen the scope of theory and measurement of personality in organizational research.

\section{Reconsidering Central Topics in Organizational Behavior Research}

Leadership. There is growing interest in issues of authenticity in organizational life (e.g., Gardner, Cogliser, Davis, \& Dickens, 2011) focused on individuals behaving in ways that reflect inner and self-transcendent values (Detert \& Bruno, 2017). For example, authentic leaders manage values such as honesty, loyalty and equality in their interaction with followers to gain relational authenticity (Avolio \& Gardner, 2005). From this perspective, leaders draw from personality resources to foster self-awareness and self-regulated positive behaviors towards their followers (Luthans \& Avolio, 2003: 243).

But the literature on individual leadership adaptability suggests that situational pressures, and the leaders' ability to change their behavior in different social situations, are important determinants of leaders' success (Blume, Baldwin, \& Ryan, 2013). There is emerging interest in 
the attributes of leaders related to behavioral adaption and change (Zaccaro, 2007: 9). Such attributes can include emotional intelligence, cognitive skills, and flexibility. And leadership research investigates whether latent leadership traits, including charisma, are socially discovered and manifested in given social situations. For example, a recent study reinterpreting charismatic leadership from a network personality perspective analyzed whether leaders who occupied positions of centrality in team advice networks exhibited emergent charisma over time or whether charismatic leaders went on to occupy central network positions (Balkundi et al., 2011). Results showed that leaders' centrality preceded the emergence of leader charisma. There is also growing interest in understanding whether and how charisma can spread from leaders to followers in organizational settings: Followers tend to imitate charismatic leaders' non-verbal behavior, enhancing in turn the expression of their personal charisma (Cherulnik et al., 2001). The growing evidence that personality can change over time triggers future research opportunities concerning whether people can develop leader-relevant personalities through the occupation of organizational roles, and whether successful leaders' personalities may change if confronted with specific social situations.

Personality-job fit. According to existing approaches to personality-job fit, people with specific attributes and traits are considered suitable to occupy specific roles in organizations (e.g., Judge et al., 2002b). In contrast, sociologists suggest that actors' occupation of positions in social and organizational systems elicit specific role behaviors. In this sense, social structures and processes "vastly transcend the individual consciousness of actors" (Lorrain \& White, 1971: 50). Personality, from a sociological view, is a set of characteristics granted by others. Each person develops a social personality that derives from occupation of "a particular place in the social space of a given society" (Warner \& Lunt, 1941: 26). Recent research in this domain 
claims that the position occupied in organizational networks (e.g., a brokerage position spanning across gaps in social structure) is an indicator itself of social personality to the extent that actors display consistency in in the network positions they occupy (Burt, 2012). Future research can examine the extent to which personality coevolves with the different roles individuals play in organizations over time (e.g., Tasselli et al., 2015).

An increased understanding of personality change and flexibility has implications for research concerning the match between people and jobs. Job demands activate specific aspects of personality with consequences for individual performance at work (Hogan \& Holland, 2003; Tett \& Burnett, 2003). And the extent to which the individual's personality is congruent with the demands of the job affects both job attitudes (e.g., O’Reilly, 1977) and job performance (e.g., Judge \& Zapata, 2015; O’Reilly, 1977). This line of research has assumed fixed personality characteristics. Future research can examine the consequences of individuals' efforts to change aspects of their personalities to fit the characteristics of jobs, and whether the occupation of idiosyncratic organizational roles, including leadership positions, can generate relevant personality change in the service of organizational functioning. Future work should also examine how personality change, triggered by network roles or external events, can produce a misfit between individuals and their career paths with outcomes that may be more positive than negative for individuals (e.g., Kleinbaum, 2012).

Task design. Not everyone may be equally capable of personality change within the context of fit with job roles. In task design research, there has been consistent interest in growth need strength, which represents the individual's desire to grow and develop within the job role (Hackman \& Oldham, 1976; Pindek, Kessler, \& Spector, 2017). Research shows that people with high growth need strength respond to supportive work contexts with more creative performance 
outcomes (Shalley, Gilson, \& Blum, 2009). Future work is needed to investigate whether interventions that have proved successful in changing personality in non-work settings are successful in affecting personality change in professional contexts in which people experience stress and work pressure.

There is also a need for further research on the extent to which managers contribute to person-job fit by assigning individuals specific roles and tasks in the organization that prompt personality change. Relatedly, the question arises as to whether organizations can improve their overall performance by stimulating employees' positive personality change via organizational and job design. Behavioral changes repeated over time can shape individuals' personality traits (Magidson et al., 2014; Roberts \& Jackson, 2008). People have agency in this process: To the extent that they invest over time in organizational roles, they tend to enhance the positive aspects of their personalities (Lodi-Smith \& Roberts, 2007). Future research can investigate the personality changes inherent in individuals' decisions to radically change their jobs and professions (e.g., Ibarra, 1999).

A further concept that may be useful in understanding the links between personality change and the social context in which jobs are executed is situational strength, defined in terms of "implicit or explicit cues provided by external entities regarding the desirability of potential behaviors" (Meyer, Dalal, \& Hermida, 2009: 122). There is debate concerning whether an employee who belongs to two or more cohesive cliques faces highly constraining pressures (Krackhardt, 1999), or whether the cross-pressures from being a "multiple insider" who brokers across cliques frees the individual to enhance innovation by transferring ideas between otherwise disconnected individuals (Vedres \& Stark, 2010). New research suggests that different personality types are differentially trusted to play this multiple insider role (Tasselli \& Kilduff, 
2017). What is unclear is whether these kinds of vital informal brokerage tasks change personality, and whether, conversely, being embedded in a single clique protects the individual from pressures to change personality.

Personnel selection and development. The use of personality measures to select people for jobs continues to generate research interest (Ryan \& Ployhart, 2013), especially given that personality is used for selection and development efforts for senior executives in organizations and for those seen as possessing high potential (Church \& Rotolo, 2013). But the view of personality as changeable casts new light on the role of personality in personnel selection and development. For example, future research can explore how trait malleability affects choices about whether to hire people whose personality profiles do not initially align with the typical candidate profile associated with job success. Is it the case that, among a set of personality traits linked with job success, some are more malleable than others? Armed with knowledge of which traits are most malleable to change over time, employers may find themselves able to make informed choices about whether new employees' organizational experiences are likely to change their traits over time, resulting in higher chances of employee success.

The emphasis in personnel management has been on the development of positive skills and abilities. Neglected in this research endeavor is the question of how dark-side personality characteristics (narcissism, Machiavellianism, psychopathy - Furnham, Richards, \& Paulhus, 2013) flourish in organizational settings, especially among chief executives (e.g., Chatterjee \& Hambrick, 2007). What aspects of organizational life may serve to reinforce and increase the prevalence of personality characteristics associated with diminished leadership effectiveness (Harms et al., 2011; Hogan, Hogan, \& Kaiser, 2010; Khoo \& Burch, 2008)?

\section{Broadening and Deepening the Scope of Theory and Measurement}


Alternatives to the Big Five. If new areas of personality change research are to be opened, then researchers have to look for evidence of personality change rather than stability. Personality change at the individual level may be "obscured or nullified" in the typical aggregate studies of the Big Five that are standard in the field (Aldwin \& Levenson, 1994). Correlations across time on personality dimensions of the order of .4 to .6 may mask evidence of considerable change at the individual as opposed to the group level (Aldwin \& Levenson, 1994; Lamiell, 1987).

Thus, the view of the Big Five as a stable input into many organizational processes (Cobb-Clark \& Schurer, 2012: 11) is challenged by the extent to which personality changes (in part driven by volitional change - Hudson \& Fraley, 2017). In organizations, the pressure for people to adapt themselves to changing roles and requirements is often intense (e.g., Raghuram, Wiesenfeld, \& Garud, 2003). If "the importance of workers' ability to adapt to novel situations in the workplace and perform at an elevated level may currently be more crucial than ever" (Huang et al., 2014: 162), then the investigation of whether, how, and when personality changes in organizations represents a vital research direction.

In contrast to prevailing orthodoxy, a change perspective on personality recognizes the flexibility of the individual in adaptation to these pressures for change. Indeed, people differ in the extent to which they adjust their underlying personality profile (in terms, for example, of the Big Five) to situational contingencies. As an indicator of this role flexibility, the self-monitoring personality construct has emerged as "especially relevant to network advantage" (Burt, Kilduff, \& Tasselli, 2013: 538) because it captures the extent to which people exhibit a flexible, responsive orientation to social cues and situational demands (Snyder, 1974). High self-monitors monitor social situations and adapt their attitudes and behaviors appropriately (Gangestad \& 
Snyder, 2000; Turnley \& Bolino, 2001), whereas low self-monitors strive to be true to themselves in terms of adhering to their core values and beliefs (see Day, Schleicher, Unckless, \& Hiller, 2002, for a meta-analysis of research in organizational settings). Research shows that self-monitoring moderates the relationship between Big Five personality traits and job performance such that Five-Factor traits are predictive of low self-monitors rather than high selfmonitors (Barrick, Parks, \& Mount, 2005; Oh, Charlier, Mount, \& Berry, 2014).

It remains an open question whether the flexible personality patterns of high selfmonitors result not just in temporary but in long-term personality change. If high self-monitors (relative to low self-monitors) tend to change more of their traits over time, then such adaptability may help explain why high self-monitors are more successful in organizational careers requiring flexibility of self-presentation (Day \& Schleicher, 2006; Kilduff \& Day, 1994).

Related to self-monitoring differences is the notion - discrepant with traditional trait approaches, including the Big Five - that people vary in the extent to which their personalities are weak or strong. The construct of personality strength is defined as "the forcefulness of implicit or explicit internal cues regarding the desirability of potential behaviors" (Dalal et al., 2015: 263). Strong personalities tend to exhibit little variance in their behavior across situations, in the same way that low self-monitors strive to maintain consistency of behavior despite environmental cues. Future research, therefore, can investigate the characteristics that differentiate weak from strong personalities, whether strong personalities exhibit little underlying personality change over time relative to weak personalities, and whether personality change is related to outcomes in organizations, such as performance, promotion, and income, according to the social situations and organizational roles that people occupy. 
To actually capture personality change at the individual as opposed to the aggregate level requires a rethinking of personality measurement. An idiographic perspective on personality offers one way to capture change at the individual level and yet preserve an overall nomothetic approach to personality differences (Lamiell, 2014). Idiographic approaches (e.g., Kelly, 1955) are able to reconcile evidence of personality change over time and situations with our sense that each individual nevertheless maintains an ongoing and distinctive self. Idiographic approaches provide an affirmative answer to the question of whether there is some psychological feature that remains stable despite the changing stream of thoughts, feelings, and behaviors that individuals exhibit.

One contemporary idiographic perspective models the variability in personality patterns over time and across social situations by way of distinctive, individual behavioral signatures (cf. Shoda, Mischel, \& Wright, 1994: 674). A professor might have a distinctive extraversion signature, for example, that includes garrulous sociability in lecturing situations and in departmental meetings combined with inhibition and restraint at social events. Idiographic perspectives can help organizational researchers understand how individuals change personality expression across organizational roles and situations even as individuals exhibit distinctive patterns of cognitive and behavioral consistency.

Broad or narrow change? The understanding of personality as a dynamic entity entails these key questions: At what level of personality is change most likely? Do people exhibit broad patterns of change in response to coworkers and job demands in the work environment? Or do people exhibit change on one or more narrower characteristics? Personality traits are typically arranged hierarchically, with broad higher-order traits such as conscientiousness subsuming narrower lower-order traits such as industriousness and orderliness (see, for example, DeYoung, 
Quilty, \& Peterson, 2007). Researchers have focused on broad patterns of personality change, given the attraction of the Big Five as a comprehensive organizing framework (e.g., see the meta-analysis of predictable mean-level change in Big Five personality dimensions over the life course: Roberts et al., 2006). But the focus on the Big Five dimensions of personality obscures potentially meaningful and interesting changes occurring at narrower, more specific aspects of the individual's personality.

Future research can explore the extent to which personality changes within narrow aspects of each of the broad traits. For example, extraversion includes both sociability and assertiveness. Working alongside a chatty coworker may promote change in the individual's sociability, but leave unchanged the individual's assertiveness. Similarly, orderliness and industriousness are both aspects of conscientiousness, and both may be changed through the dayto-day experience of working as a post office clerk. Examining change only at the level of broad traits obscures patterns of change at more granular levels of personality.

Future research, therefore, can examine how relationships in the workplace relate to change in specific facets of the individual's personality, building on recent research (Mund \& Neyer, 2014) that shows how personality measured only in terms of broad personality factors (i.e., the Big Five - Asendorpf \& Wilpers, 1998; Neyer \& Asendorpf, 2001) can obscure the effects of relationships on personality change. Mund and Neyer (2014) found numerous effects of relationship experiences on personality change with regard to narrow facets such as negative affect and self-reproach (facets of neuroticism). There were three times as many relationship effects on personality facets as compared to the broad characteristics of personality.

A useful theoretical framework for addressing levels issues emerges in trait activation theory (Tett \& Burnett, 2003) that conceives of the work environment as offering a host of 
interpersonal cues, each of which provides opportunities for trait expression. These cues come in different forms, including cues at the social level (a friendly coworker who wishes to chat), at the task level (having to discuss the features of a computer with a customer to make a sale), and at the organizational level (working in a company in which collegial values of collaboration are emphasized). Trait activation concepts are useful for understanding which aspects of personality are likely to be expressed and, by extension, undergo change over time. The behaviors that people routinely engage in can become crystallized in actual changes to underlying personality traits (Hudson \& Fraley, 2015).

\section{CONCLUSION}

Can the individual's personality change? The answer from this review is that, even without personal volition, the individual is likely to experience positive change over the life course in terms of increased social dominance, conscientiousness, and emotional stability (Roberts et al., 2006). But we have also uncovered evidence that individuals can make personal efforts to engage in habitual actions that will accumulate into trait-level personality change (e.g., Lyubomirsky et al., 2005b). Implications for organizational behavior research are profound. No longer can personality be relegated to the predictive, immutable status of an independent variable; personality can also be seen as a dependent variable - an outcome of self-development efforts, positive work environments, job roles, and work-related interactions. Of course, personality change can be inhibited by organizational routines that require people to enact precisely the same attitudes and behaviors day after day like an actor going through the motions on the stage (March \& Simon, 1958).

If the old maxim was that personality was unchanging, the new maxim from this review is that personality change is to be expected and, therefore, managed in organizations in which 
people experiment with provisional selves (e.g., Ibarra, 1999), and in which events and processes inside and outside of organizations shape personality with consequences for identity and reputation. The new view of organizations is one of arenas in which people experience profound changes to what have been considered immutable aspects of the self. Personality change may be one of the most vital outcomes of organizational experience. 


\section{REFERENCES}

Albert, S., \& Whetten, D. A. 1985. Organizational identity. Research in Organizational Behavior, 7: 263-295.

Aldwin, C. M., \& Levenson, M. R. 1994. Aging and personality assessment. In M. P. Lawton \& J. A. Teresi (Eds.), Annual review of gerontology and geriatrics: Focus on assessment techniques, 14: 182-209. New York: Springer.

Alicke, M. D., \& Sedikides, C. (Eds.) 2011. Handbook of self-enhancement and selfprotection. New York: Guilford Press.

Allport, G. W. 1937. Personality: A psychological interpretation. New York: H Holt \& Company.

Allport, G. W. 1961. Pattern and growth in personality. New York: Holt, Rinehart, \& Winston.

Allport, G. W., \& Odbert, H. S. 1936. Trait-names: A psycho-lexical study. Psychological Monographs, 47: i-171.

Asendorpf, J. B., \& Wilpers, S. 1998. Personality effects on social relationships. Journal of Personality and Social Psychology, 74: 1531-1544.

Avolio, B. J., \& Gardner, W. L. 2005. Authentic leadership development: Getting to the root of positive forms of leadership. The Leadership Quarterly, 16: 315-338.

Balkundi, P., Kilduff, M., \& Harrison, D. A. 2011. Centrality and charisma: Comparing how leader networks and attributions affect team performance. Journal of Applied Psychology, 96: 1209-1222.

Bandura, A. 1999. Moral disengagement in the perpetration of inhumanities. Personality and Social Psychology Review, 3: 193-209.

Barrick, M. R., \& Mount, M. K. 1991. The Big Five personality dimensions and job performance: A meta $\square$ analysis. Personnel Psychology, 44: 1-26.

Barrick, M. R., Parks, L., \& Mount, M. K. 2005. Self $\square$ monitoring as a moderator of the relationships between personality traits and performance. Personnel Psychology, 58: 745-767.

Baumeister, R. F., Dale, K., \& Sommer, K. L. 1998. Freudian defense mechanisms and empirical findings in modern social psychology: Reaction formation, projection, displacement, undoing, isolation, sublimation, and denial. Journal of Personality, 66: 1081-1124.

Baumeister, R. F., \& Leary, M. R. 1995. The need to belong: Desire for interpersonal attachments as a fundamental human motivation. Psychological Bulletin, 117: 497-529.

Bell, N. E., \& Staw, B. M. 1989. People as sculptors versus sculpture: The roles of personality and personal control in organizations. Handbook of Career Theory, 11: 232-250.

Bem, D. J., \& Allen, A. 1974. On predicting some of the people some of the time: The search for cross-situational consistencies in behavior. Psychological Review, 81: 506-520.

Berry, C. M., Ones, D. S., \& Sackett, P. R. 2007. Interpersonal deviance, organizational deviance, and their common correlates: A review and meta-analysis. Journal of Applied Psychology, 92: 410-424.

Block, J. H., \& Airasian, P. W. 1971. Mastery learning: Theory and practice. New York: Holt Rinehart \& Winston. 
Bloom, B. S. 1964. Stability and change in human characteristics. New York: John Wiley \& Sons.

Blume, B. D., Baldwin, T. T., \& Ryan, K. C. 2013. Communication apprehension: A barrier to students' leadership, adaptability, and multicultural appreciation. Academy of Management Learning \& Education, 12: 158-172.

Bolger, N., \& Zuckerman, A. 1995. A framework for studying personality in the stress process. Journal of Personality and Social Psychology, 69: 890-902.

Bono, J. E., \& Judge, T. A. 2004. Personality and transformational and transactional leadership: A meta-analysis. Journal of Applied Psychology, 89: 901-910.

Borman, W. C. 1987. Personal constructs, performance schemata, and "folk theories" of subordinate effectiveness: Explorations in an army officer sample. Organizational Behavior and Human Decision Processes, 40: 307-322.

Borman, W. C., Penner, L. A., Allen, T. D., \& Motowidlo, S. J. 2001. Personality predictors of citizenship performance. International Journal of Selection and Assessment, 9: 52-69.

Boyce, C. J., Wood, A. M., Daly, M., \& Sedikides, C. 2015. Personality change following unemployment. Journal of Applied Psychology, 100: 991-1011.

Brickman, P., \& Campbell, D. T. 1971. Hedonic relativism and planning the good science. In M. H. Appley (Ed.), Adaptation-level theory: 287-305. New York: Academic Press.

Brooks, D. N., \& McKinlay, W. 1983. Personality and behavioural change after severe blunt head injury - a relative's view. Journal of Neurology, Neurosurgery \& Psychiatry, 46: 336-344.

Brousseau, K. R., \& Prince, J. B. 1981. Job-person dynamics: An extension of longitudinal research. Journal of Applied Psychology, 66: 59-62.

Burt, R. S. 2012. Network-related personality and the agency question: Multirole evidence from a virtual world. American Journal of Sociology, 118: 543-591.

Burt, R. S., Kilduff, M., \& Tasselli, S. 2013. Social network analysis: Foundations and frontiers on advantage. Annual Review of Psychology, 64: 527-547.

Cacioppo, J. T., Fowler, J. H., \& Christakis, N. A. 2009. Alone in the crowd: The structure and spread of loneliness in a large social network. Journal of Personality and Social Psychology, 97: 977-991.

Cahalan, D., Cisin, I. H., \& Crossley, H. M. 1969. American drinking practices: A national study of drinking behavior and attitudes. Monographs of the Rutgers Center of Alcohol Studies.

Carver, C. S., \& Scheier, M. F. 2002. The hopeful optimist. Psychological Inquiry, 13: 288-290.

Casciaro, T., Barsade, S. G., Edmondson, A. C., Gibson, C. B., Krackhardt, D., \& Labianca, G. 2015. The integration of psychological and network perspectives in organizational scholarship. Organization Science, 26: 1162-1176.

Chapman, B. P., Hampson, S., \& Clarkin, J. 2014. Personality-informed interventions for healthy aging: Conclusions from a National Institute on Aging work group. Developmental Psychology, 50: 1426-1441.

Chatterjee, A., \& Hambrick, D. C. 2007. It's all about me: Narcissistic chief executive officers and their effects on company strategy and performance. Administrative Science Quarterly, 52: 351-386. 
Cherulnik, P. D., Donley, K. A., Wiewel, T. S. R., \& Miller, S. R. 2001. Charisma is contagious: The effect of leaders' charisma on observers' affect. Journal of Applied Social Psychology, 31: 2149-2159.

Church, A. H., \& Rotolo, C. T. 2013. How are top companies assessing their high-potentials and senior executives? A talent management benchmark study. Consulting Psychology Journal: Practice and Research, 65: 199-223.

Clark, D. M., Ehlers, A., McManus, F., Hackmann, A., Fennell, M., Campbell, H., Flower, T., Davenport, C., \& Louis, B. 2003. Cognitive therapy versus fluoxetine in generalized social phobia: A randomized placebo-controlled trial. Journal of Consulting and Clinical Psychology, 71: 1058-1067.

Cloninger, C. R. 1986. A unified biosocial theory of personality and its role in the development of anxiety states. Psychiatric Developments, 3: 167-226.

Cobb-Clark, D. A., \& Schurer, S. 2012. The stability of Big Five personality traits. Economics Letters, 115: 11-15.

Cohen, G. L., \& Garcia, J. 2008. Identity, belonging, and achievement: A model, interventions, implications. Current Directions in Psychological Science, 17: 365-369.

Cohen, G. L., \& Sherman, D. K. 2014. The psychology of change: Self-affirmation and social psychological intervention. Annual Review of Psychology, 65: 333-371.

Colbert, A. E., Bono, J. E., \& Purvanova, R. K. 2016. Flourishing via workplace relationships: Moving beyond instrumental support. Academy of Management Journal, 59: 1199_ 1223.

Collins, C. J., Hanges, P. J., \& Locke, E. A. 2004. The relationship of achievement motivation to entrepreneurial behavior: A meta-analysis. Human Performance, 17: 95-117.

Cornelius, N. 2015. Personal construct theory, research, and practice in the field of business and management. In D. A. Winter \& N. Reed (Eds.), The Wiley handbook of personal construct psychology: 267-281. Chichester, UK: John Wiley \& Sons.

Costa, P. T., \& Mccrae, R. R. 1998. Trait theories of personality. In D. F. Barone, M. Hersen, \& V. B. V. Hasselt (Eds), Advanced personality: 103-121. New York: Plenum.

Cuijpers, P., Donker, T., van Straten, A., Li, J., \& Andersson, G. 2010. Is guided self-help as effective as face-to-face psychotherapy for depression and anxiety disorders? A systematic review and meta-analysis of comparative outcome studies. Psychological Medicine, 40: 1943-1957.

Dabbs, J. M., Hargrove, M. F., \& Heusel, C. 1996. Testosterone differences among college fraternities: Well-behaved vs. rambunctious. Personality and Individual Differences, 20: $157-161$.

Dalal, R. S., Meyer, R. D., Bradshaw, R. P., Green, J. P., Kelly, E. D., \& Zhu, M. 2015. Personality strength and situational influences on behavior: A conceptual review and research agenda. Journal of Management, 41: 261-287.

Davis-Blake, A., \& Pfeffer, J. 1989. Just a mirage: The search for dispositional effects in organizational research. Academy of Management Review, 14: 385-400.

Day, D. V., \& Schleicher, D. J. 2006. Self $\square$ monitoring at work: A motive $\square$ based perspective. Journal of Personality, 74: 685-714. 
Day, D. V., Shleicher, D. J., Unckless, A. L., \& Hiller, N. J. 2002. Self-monitoring personality at work: A meta-analytic investigation of construct validity. Journal of Applied Psychology, 87: 390-401.

Deinert, A., Homan, A. C., Boer, D., Voelpel, S. C., \& Gutermann, D. 2015. Transformational leadership sub-dimensions and their link to leaders' personality and performance. The Leadership Quarterly, 26: 1095-1120.

Detert, J., \& Bruno, E. 2017. Workplace courage: Review, synthesis, and future agenda for a complex construct. Academy of Management Annals. Forthcoming.

de Vries, T. A., Walter, F., Van der Vegt, G. S., \& Essens, P. J. 2014. Antecedents of individuals' interteam coordination: Broad functional experiences as a mixed blessing. Academy of Management Journal, 57: 1334-1359.

DeYoung, C. G., Quilty, L. C., \& Peterson, J. B. 2007. Between facets and domains: Ten aspects of the Big Five. Journal of Personality and Social Psychology, 93: 880-96.

Dickie, V. A. 2003. Establishing worker identity: A study of people in craftwork. American Journal of Occupational Therapy, 57: 250-261.

Didehbani, N., Cullum, C. M., Mansinghani, S., Conover, H., \& Hart, J. 2013. Depressive symptoms and concussions in aging retired NFL players. Archives of Clinical Neuropsychology, 28: 418-424.

Du, L., Bakish, D., Ravindran, A. V., \& Hrdina, P. D. 2002. Does fluoxetine influence major depression by modifying five-factor personality traits?. Journal of Affective Disorders, 71: $235-241$.

Dweck, C. S. 1999. Self-theories: Their role in motivation, personality and development. Philadelphia: Taylor and Francis/Psychology Press.

Dweck, C. S. 2008. Can personality be changed? The role of beliefs in personality and change. Current Directions in Psychological Science, 17: 391-394.

Eden, C., \& Ackermann, F. 2010. Decision making in groups: Theory and practice. In P. C. Nutt \& D. C. Wilson (Eds.), Handbook of decision making: 231-272. Chichester, UK: John Wiley \& Sons.

Edmonds, G. W., Jackson, J. J., Fayard, J. V, \& Roberts, B. W. 2008. Is character fate, or is there hope to change my personality yet? Social and Personality Psychology Compass, 2: 399-413.

Epstein, S., \& O'Brien, E. J. 1985. The person-situation debate in historical and current perspective. Psychological Bulletin, 98: 513-537.

Ertug, G., \& Castellucci, F. 2013. Getting what you need: How reputation and status affect team performance, hiring, and salaries in the NBA. Academy of Management Journal, 56: $407-431$.

Fang, R., Landis, B., Zhang, Z., Anderson, M. H., Shaw, J. D., \& Kilduff, M. 2015. Integrating personality and social networks: A meta-analysis of personality, network position, and work outcomes in organizations. Organization Science, 26: 1243-1260.

Farmer, R. F., \& Chapman, A. L. 2016. Behavioral activation. Washington D.C.: American Psychological Association. 
Feiler, D. C., \& Kleinbaum, A. M. 2015. Popularity, similarity, and the network extraversion bias. Psychological Science, 26: 593-603.

Fink, K. 2003. Magnitude of trauma and personality change. The International Journal of Psychoanalysis, 84: 985-995.

Fleeson, W. 2004. Moving personality beyond the person-situation debate: The challenge and the opportunity of within-person variability. Current Directions in Psychological Science, 13: $83-87$.

Foulk, T., Woolum, A., \& Erez, A. 2016. Catching rudeness is like catching a cold: The contagion effects of low-intensity negative behaviors. Journal of Applied Psychology, 101: 50-67.

Fowler, J. H., \& Christakis, N. A. 2008. Dynamic spread of happiness in a large social network: longitudinal analysis over 20 years in the Framingham Heart Study. British Medical Journal, 337: a2338.

Freud, S. 1923. The ego and the id. Standard edition, 19: 3-66. London: Hogarth Press.

Funder, D. C. 1991. Global traits: A neo-Allportian approach to personality. Psychological Science, 2: 31-39.

Funder, D. C. 1997. The personality puzzle. New York: W. W. Norton \& Co.

Furnham, A., Richards, S. C., \& Paulhus, D. L. 2013. The Dark Triad of personality: A 10 year review. Social and Personality Psychology Compass, 7: 199-216.

Gable, S. L., \& Haidt, J. 2005. What (and why) is positive psychology? Review of General Psychology, 9: 103-110.

Gangestad, S. W., \& Snyder, M. 2000. Self-monitoring: Appraisal and reappraisal. Psychological Bulletin, 126: 530-555.

Garcia, J., \& Cohen, G. L. 2013. A social psychological approach to educational intervention. In E. Shafir (Ed.), The behavioral foundations of policy: 329-350. Princeton, NJ: Princeton University Press.

Gardner, W. L., Cogliser, C. C., Davis, K. M., \& Dickens, M. P. 2011. Authentic leadership: A review of the literature and research agenda. The Leadership Quarterly, 22: 1120-1145.

Gendlin, E. T. 1964. A theory of personality change. In P. Worchel \& D. Byrne (Eds.), Personality change: 100-148. New York: John Wiley \& Sons.

Gerhart, B. 1987. How important are dispositional factors as determinants of job satisfaction? Implications for job design and other personnel programs. Journal of Applied Psychology, 72: 366-373.

Gerhart, B. 2005. The (affective) dispositional approach to job satisfaction: Sorting out the policy implications. Journal of Organizational Behavior, 26: 79-97.

Gioia, D. A., Schultz, M., \& Corley, K. G. 2000. Organizational identity, image, and adaptive instability. Academy of Management Review, 25: 63-81.

Glenn, N. D. 1980. Values, attitudes, and beliefs. In O. G. Brim, Jr. \& J. Kagan (Eds.), Constancy and change in human development: 596-640. Cambridge, MA: Harvard University Press.

Goffman, E. 1961. On the characteristics of total institutions. In Symposium on preventive and social psychiatry: 43-84. Washington D.C.: Walter Reed Army Medical Centre. 
Goldberg, L. R. 1993. The structure of phenotypic personality traits. American Psychologist, 48: 26-34.

Grant, A. M., \& Parker, S. K. 2009. Redesigning work design theories: The rise of relational and proactive perspectives. Academy of Management Annals, 3: 317-375.

Grounds, A. 2004. Psychological consequences of wrongful conviction and imprisonment. Canadian Journal of Criminology and Criminal Justice, 46: 165-182.

Guiora, A. Z., \& Acton, W. R. 1979. Personality and language behavior: A restatement. Language Learning, 29: 193-204.

Hackman, J. R., \& Oldham, G. R. 1976. Motivation through the design of work: Test of a theory. Organizational Behavior and Human Performance, 16: 250-279.

Halbesleben, J. R., \& Bowler, W. M. 2007. Emotional exhaustion and job performance: The mediating role of motivation. Journal of Applied Psychology, 92: 93-106.

Hall, D. 1995. Unplanned executive transitions and the dance of subidentities. Human Resource Management, 34: 71-92.

Hampson, S. E., \& Goldberg, L. R. 2006. A first large cohort study of personality trait stability over the 40 years between elementary school and midlife. Journal of Personality and Social Psychology, 91: 763-779.

Harms, P. D., Roberts, B. W., \& Winter, D. 2006. Becoming the Harvard man: Personenvironment fit, personality development, and academic success. Personality and Social Psychology Bulletin, 32: 851-865.

Harms, P. D., Spain, S. M., \& Hannah, S. T. 2011. Leader development and the dark side of personality. The Leadership Quarterly, 22: 495-509.

Harris, M. A., Brett, C. E., Johnson, W., \& Deary, I. J. 2016. Personality stability from age 14 to age 77 years. Psychology and Aging, 31: 862-874.

Harrison, D. A., Newman, D. A., \& Roth, P. L. 2006. How important are job attitudes? Metaanalytic comparisons of integrative behavioral outcomes and time sequences. Academy of Management Journal, 49: 305-325.

Hennecke, M., \& Freund, A. M. 2017. The development of goals and motivation. In J. Specht (Ed.), Personality development across the lifespan: 257-273. London: Academic Press.

Hicks, B. M., Durbin, C. E., Blonigen, D. M., Iacono, W. G., \& McGue, M. 2012. Relationship between personality change and the onset and course of alcohol dependence in young adulthood. Addiction, 107: 540-548.

Hobfoll, S. E. 1989. Conservation of resources: A new attempt at conceptualizing stress. American Psychologist, 44: 513-524.

Hogan, J., Hogan, R., \& Kaiser, R. B. 2010. Management derailment. APA Handbook of Industrial and Organizational Psychology, 3: 555-575.

Hogan, J., \& Holland, B. 2003. Using theory to evaluate personality and job-performance relations: A socioanalytic perspective. Journal of Applied Psychology, 88: 100-112.

Hogan, R. 1982. A socioanalytic theory of personality. In M. Page \& R. Dienstbier (Eds.), Nebraska Symposium on Motivation: 55-89. Lincoln: University of Nebraska Press.

Hogan, R. 1996. A socioanalytic perspective. In J. S. Wiggins (Ed.), The five-factor model of personality: Theoretical perspectives: 163-217. New York: Guilford Press. 
Huang, J. L., Ryan, A. M., Zabel, K. L., \& Palmer, A. 2014. Personality and adaptive performance at work: A meta-analytic investigation. Journal of Applied Psychology, 99: $162-179$.

Hudson, N. W., \& Fraley, R. C. 2015. Volitional personality trait change: Can people choose to change their personality traits? Journal of Personality and Social Psychology, 109: 490 507.

Hudson, N. W., \& Fraley, R. C. 2016. Changing for the better? Longitudinal associations between volitional personality change and psychological well-being. Personality and Social Psychology Bulletin, 42: 603-615.

Hudson, N. W., \& Fraley, R. C. 2017. Volitional personality change. In J. Specht (Ed.), Personality development across the lifespan: 401-417. London: Academic Press.

Hudson, N. W., \& Roberts, B. W. 2016. Social investment in work reliably predicts change in conscientiousness and agreeableness: A direct replication and extension of Hudson, Roberts, and Lodi-Smith (2012). Journal of Research in Personality, 60: 12-23.

Hülür, G. 2017. Cohort differences in personality. In J. Specht (Ed.), Personality development across the lifespan: 520-536. London: Academic Press.

Ibarra, H. 1999. Provisional selves: Experimenting with image and identity in professional adaptation. Administrative Science Quarterly, 44: 764-791.

Jackson, J. J. 2011. The effects of educational experiences on personality trait development. Unpublished doctoral dissertation, University of Illinois, Urbana-Champaign.

Jackson, J. J., Bogg, T., Walton, K. E., Wood, D., Harms, P. D., Lodi-Smith, J., Edmonds, G. W., \& Roberts, B. W. 2009. Not all conscientiousness scales change alike: A multimethod, multisample study of age differences in the facets of conscientiousness. Journal of Personality and Social Psychology, 96: 446-459.

Jackson, J. J., Thoemmes, F., Jonkmann, K., Lüdtke, O., \& Trautwein, U. 2012. Military training and personality trait development: Does the military make the man, or does the man make the military? Psychological Science, 23: 270-277.

James, W. 1890. The principles of psychology (2 vols). New York: Henry Holt.

James, W. 1988. The moral equivalent of war. In B. Kuklick (Ed.), Writings 1902-1910: 12811293. New York: Library of America. (Original work published 1910).

Jang, K. L., McCrae, R. R., Angleitner, A., Riemann, R., \& Livesley, W. J. 1998. Heritability of facet-level traits in a cross-cultural twin sample: Support for a hierarchical model of personality. Journal of Personality and Social Psychology, 74: 1556-1565.

Jayawickreme, E., \& Blackie, L. E. 2014. Post $\square$ traumatic growth as positive personality change: Evidence, controversies and future directions. European Journal of Personality, 28: 312-331.

Johnson, W., McGue, M., \& Krueger, R. F. 2005. Personality stability in late adulthood: A behavioral genetic analysis. Journal of Personality, 73: 523-552.

Jokela, M., Kivimäki, M., Elovainio, M., \& Keltikangas-Järvinen, L. 2009. Personality and having children: A two-way relationship. Journal of Personality and Social Psychology, 96: $218-230$.

Judge, T. A., Bono, J. E., Ilies, R., \& Gerhardt, M. W. 2002a. Personality and leadership: A qualitative and quantitative review. Journal of Applied Psychology, 87: 765-780. 
Judge, T. A., Cable, D. M., Boudreau, J. W., \& Bretz, R. D. 1995. An empirical investigation of the predictors of executive career success. Personnel Psychology, 48: 485-519.

Judge, T. A., Heller, D., \& Mount, M. K. 2002b. Five-factor model of personality and job satisfaction: A meta-analysis. Journal of Applied Psychology, 87: 530-541.

Judge, T. A., \& Ilies, R. 2002. Relationship of personality to performance motivation: A metaanalytic review. Journal of Applied Psychology, 87: 797-807.

Judge, T. A., \& Zapata, C. P. 2015. The person-situation debate revisited: Effect of situation strength and trait activation on the validity of the Big Five personality traits in predicting job performance. Academy of Management Journal, 58: 1149-1179.

Kahn, W. A. 1990. Psychological conditions of personal engagement and disengagement at work. Academy of Management Journal, 33: 692-724.

Kelly, G. A. 1955. The psychology of personal constructs (2 vols). New York: W. W. Norton \& Co.

Kelly, G. A. 1963. A theory of personality. New York: W. W. Norton \& Co.

Khoo, H. S., \& Burch, G. S. J. 2008. The "dark side"of leadership personality and transformational leadership: An exploratory study. Personality and Individual Differences, 44: 86-97.

Kilduff, M., Crossland, C., Tsai, W., \& Bowers, M. T. 2016. Magnification and correction of the acolyte effect: Initial benefits and ex post settling up in NFL coaching careers. Academy of Management Journal, 59: 352-375.

Kilduff, M., \& Day, D. V. 1994. Do chameleons get ahead? The effects of self-monitoring on managerial careers. Academy of Management Journal, 37: 1047-1060.

Klein, K. J., Lim, B. C., Saltz, J. L., \& Mayer, D. M. 2004. How do they get there? An examination of the antecedents of centrality in team networks. Academy of Management Journal, 47: 952-963.

Kleinbaum, A. M. 2012. Organizational misfits and the origins of brokerage in intrafirm networks. Administrative Science Quarterly, 57: 407-452.

Kohn, M. L., \& Schooler, C. 1978. The reciprocal effects of the substantive complexity of work and intellectual flexibility: A longitudinal assessment. American Journal of Sociology, 84: 24-52.

Kouchaki, M., \& Desai, S. D. 2015. Anxious, threatened, and also unethical: How anxiety makes individuals feel threatened and commit unethical acts. Journal of Applied Psychology, 100: 360-375.

Krackhardt, D. 1999. The ties that torture: Simmelian tie analysis in organizations. Research in the Sociology of Organizations, 16: 183-210.

Lamb, H. R., \& Weinberger, L. E. 1998. Persons with severe mental illness in jails and prisons: A review. Psychiatric Services, 43: 483-492.

Lamiell, J. T. 1987. The psychology of personality: An epistemological inquiry. New York: Columbia University Press.

Lamiell, J. T. 2014. The case for an idiothetic psychology of personality: A conceptual and empirical foundation. Progress in Experimental Personality Research, 11: 1-64.

Landis, B. 2016. Personality and social networks in organizations: A review and future directions. Journal of Organizational Behavior, 31: S107-S121. 
Lehnart, J., \& Neyer, F. J. 2006. Should I stay or should I go? Attachment and personality in stable and instable romantic relationships. European Journal of Personality, 20: 475495.

Li, N., Barrick, M. R., Zimmerman, R. D., \& Chiaburu, D. S. 2014. Retaining the productive employee: The role of personality. Academy of Management Annals, 8: 347-395.

Li, W. D., Fay, D., Frese, M., Harms, P. D., \& Gao, X. Y. 2014. Reciprocal relationship between proactive personality and work characteristics: A latent change score approach. Journal of Applied Psychology, 99: 948-965.

Little, B. R. 1983. Personal projects: A rationale and method for investigation. Environment and Behavior, 15: 273-309.

Littlefield, A. K., Sher, K. J., \& Wood, P. K. 2009. Is "maturing out" of problematic alcohol involvement related to personality change? Journal of Abnormal Psychology, 118: 360374.

Liu, J., Chen, X., Li, D., \& French, D. 2012. Shyness $\square$ sensitivity, aggression, and adjustment in urban Chinese adolescents at different historical times. Journal of Research on Adolescence, 22: 393-399.

Lodi-Smith, J., \& Roberts, B. W. 2007. Social investment and personality: A meta-analysis of the relationship of personality traits to investment in work, family, religion, and volunteerism. Personality and Social Psychology Review, 11: 68-86.

Lorrain, F., \& White, H. C. 1971. Structural equivalence of individuals in social networks. Journal of Mathematical Sociology, 1: 49-80.

Lucas, R. E., Clark, A. E., Georgellis, Y., \& Diener, E. 2004. Unemployment alters the set point for life satisfaction. Psychological Science, 15: 8-13.

Lüdtke, O., Roberts, B. W., Trautwein, U., \& Nagy, G. 2011. A random walk down university avenue: Life paths, life events, and personality trait change at the transition to university life. Journal of Personality and Social Psychology, 101: 620-637.

Luthans, F. 2002. The need for and meaning of positive organizational behavior. Journal of Organizational Behavior, 23: 695-706.

Luthans, F., \& Avolio, B. J. 2003. Authentic leadership: A positive development approach. In K. S. Cameron, J. E. Dutton, \& R. E. Quinn (Eds.), Positive organizational scholarship: 241-261. San Francisco: Barrett-Koehler.

Lykken, D., \& Tellegen, A. 1996. Happiness is a stochastic phenomenon. Psychological Science, 7: 186-189.

Lyubomirsky, S., King, L., \& Diener, E. 2005a. The benefits of frequent positive affect: Does happiness lead to success? Psychological Bullettin, 131: 803-855.

Lyubomirsky, S., Sheldon, K. M., \& Schkade, D. 2005a. Pursuing happiness: The architecture of sustainable change. Review of General Psychology, 9: 111-131.

Magidson, J. F., Roberts, B. W., Collado-Rodriguez, A., \& Lejuez, C. W. 2014. Theory-driven intervention for changing personality: Expectancy value theory, behavioral activation, and conscientiousness. Developmental Psychology, 50: 1442-1450.

Mahoney, M. J. 2002. Constructivism and positive psychology. In C. R. Snyder \& S. J. Lopez (Eds.), Handbook of positive psychology: 45-750. New York: Oxford University Press.

March, J. G., \& Simon, H. A. 1958. Organizations. New York: John Wiley \& Sons. 
Maslow, A. 1954. Motivation and personality. New York: Harper \& Row.

Maslow, A. 1968. Toward a psychology of being. New York: Van Nostrand.

Maurer, T. J., \& Lippstreu, M. 2008. Expert vs. general working sample differences in KSAO "improvability" ratings and relationships with measures relevant to occupational and organizational psychology. Journal of Occupational and Organizational Psychology, 81: 813-829.

McAdams, D. P. 1993. The stories we live by: Personal myths and the making of the self. New York: Guilford Press.

McClelland, D. C. 1965. Toward a theory of motive acquisition. American Psychologist, 20: 321-333.

McClelland, D. C. 1987. Human motivation. New York: Cambridge University Press.

McCrae, R. R., \& Costa, P. T. 1994. The stability of personality: Observations and evaluations. Current Directions in Psychological Science, 3: 173-175.

McCrae, R. R., \& Costa, P. T. 2003. Personality in adulthood: A five-factor theory perspective. New York: Guilford Press.

McCrae, R. R., \& Costa, P. T. 2008. Empirical and theoretical status of the five-factor model of personality traits. In G. Boyle, G. Matthews, \& D. H. Saklofske (Eds.), The SAGE handbook of personality theory and assessment: 273-294. Thousand Oaks, CA: Sage.

McLean, K. C. 2017. And the story evolves: The development of personal narratives and narrative identity. In J. Specht (Ed.), Personality development across the lifespan: $325-$ 338. London: Academic Press.

McQueen, A., \& Klein, W. M. 2006. Experimental manipulations of self-affirmation: A systematic review. Self Identity, 5: 289-354.

Meyer, R. D., Dalal, R. S., \& Hermida, R. 2009. A review and synthesis of situational strength in the organizational sciences. Journal of Management, 36: 121-140.

Miller, A. 2008. A critique of positive psychology - or "the new science of happiness". Journal of Philosophy of Education, 42: 591-608.

Mischel, W. 1968. Personality and assessment. London: John Wiley \& Sons.

Mischel, W. 1973. Toward a cognitive social learning reconceptualization of personality. Psychological Review, 80: 252-283.

Mischel, W. 1979. On the interface of cognition and personality: Beyond the person-situation debate. American Psychologist, 34: 740-754.

Mischel, W. 2004. Toward an integrative science of the person. Annual Review of Psychology, 55: $1-22$.

Mischel, W., \& Shoda, Y. 1995. A cognitive-affective system theory of personality: Reconceptualizing situations, dispositions, dynamics, and invariance in personality structure. Psychological Review, 102: 246-268.

Mitchell, T. R. 1997. Matching motivational strategies with organizational contexts. Research in Organizational Behavior, 19: 57-150.

Mortimer, J. T., \& Lorence, J. 1979. Work experience and occupational value socialization: A longitudinal study. American Journal of Sociology, 84: 1361-1385. 
Mroczek, D. K., Almeida, D. M., Spiro, A., \& Pafford, C. 2006. Modeling intraindividual stability and change in personality. In D. K. Mroczek \& T. D. Little (Eds.), Handbook of personality development: 163-180. Mahwah, NJ: Lawrence Erlbaum Associates.

Mroczek, D. K., \& Spiro, A. 2007. Personality change influences mortality in older men. Psychological Science, 18: 371-376.

Mund, M., \& Neyer, F. J. 2014. Treating personality-relationship transactions with respect: Narrow facets, advanced models, and extended time frames. Journal of Personality and Social Psychology, 107: 352-368.

Murray, H. A. 1938. Explorations in personality. Oxford, UK: Oxford University Press.

Neimeyer, R. A. 1993. An appraisal of constructivist psychotherapies. Journal of Consulting and Clinical Psychology, 61: 221-234.

Neyer, F. J., \& Asendorpf, J. B. 2001. Personality-relationship transaction in young adulthood. Journal of Personality and Social Psychology, 81: 1190-1204.

Neyer, F. J., \& Lehnart, J. 2007. Relationships matter in personality development: Evidence from an $8 \square$ year longitudinal study across young adulthood. Journal of Personality, 75: 535568.

Niess, C. 2014. Reciprocal influences between personality traits and career transitions. Unpublished doctoral dissertation, University of Cologne.

Oh, I. S., Charlier, S. D., Mount, M. K., \& Berry, C. M. 2014. The two faces of high self $\square$ monitors: Chameleonic moderating effects of self $\square$ monitoring on the relationships between personality traits and counterproductive work behaviors. Journal of Organizational Behavior, 35: 92-111.

O'Reilly, C. A. 1977. Personality-job fit: Implications for individual attitudes and performance. Organizational Behavior and Human Performance, 18: 36-46.

Organ, D. W., Podsakoff, P. M., \& Podsakoff, N. P. 2010. Expanding the criterion domain to include organizational citizenship behavior: Implications for employee selection. In $\mathrm{S}$. Zedeck (Ed.), APA handbook of industrial and organizational psychology: 281-323. Washington D.C.: American Psychological Association.

Organ, D. W., \& Ryan, K. 1995. A meta $\square$ analytic review of attitudinal and dispositional predictors of organizational citizenship behavior. Personnel Psychology, 48: 775-802.

Parker, S. K., \& Collins, C. G. 2010. Taking stock: Integrating and differentiating multiple proactive behaviors. Journal of Management, 36: 633-662.

Pervin, L. A. 1994. A critical analysis of current trait theory. Psychological Inquiry, 5: 103-113.

Piedmont, R. L. 2001. Cracking the plaster cast: Big Five personality change during intensive outpatient counseling. Journal of Research in Personality, 35: 500-520.

Pindek, S., Kessler, S. R., \& Spector, P. E. 2017. A quantitative and qualitative review of what meta-analyses have contributed to our understanding of human resource management. Human Resource Management Review, 27: 26-38.

Podolny, J. M. 2001. Networks as the pipes and prisms of the market. American Journal of Sociology, 107: 33-60. 
Pratt, M. G., Rockmann, K. W., \& Kaufmann, J. B. 2006. Constructing professional identity: The role of work and identity learning cycles in the customization of identity among medical residents. Academy of Management Journal, 49: 235-262.

Priesemuth, M., \& Taylor, R. M. 2016. The more I want, the less I have left to give: The moderating role of psychological entitlement on the relationship between psychological contract violation, depressive mood states, and citizenship behavior. Journal of Organizational Behavior, 37: 967-982.

Raghuram, S., Wiesenfeld, B., \& Garud, R. 2003. Technology enabled work: The role of selfefficacy in determining telecommuter adjustment and structuring behavior. Journal of Vocational Behavior, 63: 180-198.

Ragins, B. R., Lyness, K. S., Williams, L. J., \& Winkel, D. 2014. Life spillovers: The spillover of fear of home foreclosure to the workplace. Personnel Psychology, 67: 763-800.

Reger, R. K., Gustafson, L. T., Demarie, S. M., \& Mullane, J. V. 1994. Reframing the organization: Why implementing total quality is easier said than done. Academy of Management Review, 19: 565-584.

Robbins, B. D. 2008. What is the good life? Positive psychology and the renaissance of humanistic psychology. The Humanistic Psychologist, 36: 96-112.

Robbins, S. P., \& Judge, T. A. 2017. Organizational behavior. Harlow, UK: Pearson.

Roberts, B. W. 1997. Plaster or plasticity: Are work experiences associated with personality change in women? Journal of Personality, 65: 205-232.

Roberts, B. W., Caspi, A., \& Moffitt, T. E. 2003. Work experiences and personality development in young adulthood. Journal of Personality and Social Psychology, 84: 582-593.

Roberts, B. W., \& Donahue, E. M. 1994. One personality, multiple selves: Integrating personality and social roles. Journal of Personality, 62: 199-218.

Roberts, B. W., \& Jackson, J. J. 2008. Sociogenomic personality psychology. Journal of Personality, 76: 1523-1544.

Roberts, B. W., Kuncel, N. R., Shiner, R., Caspi, A., \& Goldberg, L. R. 2007. The power of personality: The comparative validity of personality traits, socioeconomic status, and cognitive ability for predicting important life outcomes. Perspectives on Psychological Science, 2: 313-345.

Roberts, B. W., Luo, J., Briley, D. A., Chow, P. I., Su, R., \& Hill, P. L. 2017. A systematic review of personality trait change through intervention. Pyschological Bullettin, 143: $117-141$.

Roberts, B. W., \& Mroczek, D. 2008. Personality trait change in adulthood. Current Directions in Psychological Science, 17: 31-35.

Roberts, B. W., \& Nickel, L. B. 2017. A critical evaluation of the neo-socioanalytic model of personality. In J. Specht (Ed.), Personality development across the lifespan: 157-177. London: Academic Press.

Roberts, B. W., Walton, K. E., \& Viechtbauer, W. 2006. Patterns of mean-level change in personality traits across the life course: A meta-analysis of longitudinal studies. Psychological Bulletin, 132: 1-25. 
Roberts, B. W., \& Wood, D. 2006. Personality development in the context of the neosocioanalytic model of personality. In D. K. Mroczek \& T. D. Little (Eds.), Handbook of personality development: 11-39. Mahwah, NJ: Lawrence Erlbaum Associates.

Roberts, B. W., Wood, D., \& Caspi, A. 2008. The development of personality traits in adulthood. Handbook of personality: Theory and research: 3, 375-398.

Roberts, L. M., Dutton, J. E., Spreitzer, G. M., Heaphy, E. D., \& Quinn, R. E. 2005. Composing the reflected best-self portrait: Building pathways for becoming extraordinary in work organizations. Academy of Management Review, 30: 712-736.

Rogers, C. R. 1947. Some observations on the organization of personality. American Psychologist, 2: 358-368.

Rogers, C. R. 2007. The necessary and sufficient conditions of therapeutic personality change. Psychotherapy: Theory, Research, Practice, Training, 3: 240-248.

Rogers, C. R. 2012. On becoming a person: A therapist's view of psychotherapy. Boston: Houghton Mifflin Harcourt.

Rosenquist, J. N., Fowler, J. H., \& Christakis, N. A. 2011. Social network determinants of depression. Molecular Psychiatry, 16: 273-281.

Rothbart, M. K., Ahadi, S. A., \& Evans, D. E. 2000. Temperament and personality: Origins and outcomes. Journal of Personality and Social Psychology, 78: 122-135.

Rotter, J. B. 1954. Social learning and clinical psychology. Englewood Cliffs, NJ: PrenticeHall.

Ryan, A. M., \& Ployhart, R. E. 2013. Customer service behavior. Handbook of Psychology, 12: 341-366.

Sabelli, H. C., \& Carlson-Sabelli, L. 1989. Biological priority and psychological supremacy: A new interrogative paradigm derived from process theory. The American Journal of Psychiatry, 146: 1541-1551.

Sackett, P. R. 2002. The structure of counterproductive work behaviors: Dimensionality and relationships with facets of job performance. International Journal of Selection and Assessment, 10: 5-11.

Salancik, G. R., \& Pfeffer, J. 1978. A social information processing approach to job attitudes and task design. Administrative Science Quarterly, 23: 224-253.

Sapir, E. 1934. The emergence of the concept of personality in a study of cultures. Journal of Social Psychology, 5: 408-415.

Schmitt, N. 2014. Personality and cognitive ability as predictors of effective performance at work. Annual Review of Organizational Psychology and Organizational Behavior, 1: 45-65.

Schneider, B., Smith, D. B., Taylor, S., \& Fleenor, J. 1998. Personality and organizations: A test of the homogeneity of personality hypothesis. Journal of Applied Psychology, 83: 462470.

Schult, J., \& Sparfeldt, J. R. 2015. Compulsory military service and personality development. SOEPpaper, No. 751. Available at https://ssrn.com/abstract=2602703

Scollon, C. N., \& Diener, E. 2006. Love, work, and changes in extraversion and neuroticism over time. Journal of Personality and Social Psychology, 91: 1152-1165. 
Seligman, M. E. P., \& Csikszentmihalyi, M. 2000. Positive psychology: An introduction. American Psychologist, 55: 5-14.

Shalley, C. E., Gilson, L. L., \& Blum, T. C. 2009. Interactive effects of growth need strength, work context, and job complexity on self-reported creative performance. Academy of Management Journal, 52: 489-505.

Shoda, Y., Mischel, W., \& Wright, J. C. 1994. Intraindividual stability in the organization and patterning of behavior: Incorporating psychological situations into the idiographic analysis of personality. Journal of Personality and Social Psychology, 67: 674-687.

Smith, M. L., Glass, G. V., \& Miller, T. I. 1980. The benefits of psychotherapy. Baltimore, MD: Johns Hopkins University Press.

Snyder, C. R., \& Lopez, S. J. (Eds.). 2009. Oxford handbook of positive psychology. New York: Oxford University Press.

Snyder, M. 1974. Self-monitoring of expressive behavior. Journal of Personality and Social Psychology, 30: 526-537.

Soldz, S., \& Vaillant, G. E. 1999. The Big Five personality traits and the life course: A 45-year longitudinal study. Journal of Research in Personality, 33: 208-232.

Soskin, D. P., Carl, J. R., Alpert, J., \& Fava, M. 2012. Antidepressant effects on emotional temperament: Toward a biobehavioral research paradigm for major depressive disorder. CNS Neuroscience \& Therapeutics, 18: 441-451.

Soto, C. 2016. Personality can change over a lifetime, and usually for the better. Health News from National Public Radio. Available at http://www.npr.org/sections/healthshots/2016/06/30/484053435/personality-can-change-over-a-lifetime-and-usually-for-thebetter [accessed on July 5, 2016]

Specht, J., Egloff, B., \& Schmukle, S. C. 2011. Stability and change of personality across the life course: The impact of age and major life events on mean-level and rank-order stability of the Big Five. Journal of Personality and Social Psychology, 101: 862-882.

Srivastava, S., John, O. P., Gosling, S. D., \& Potter, J. 2003. Development of personality in early and middle adulthood: Set like plaster or persistent change? Journal of Personality and Social Psychology, 84: 1041-1053.

Staw, B. M., Bell, N. E., \& Clausen, J. A. 1986. The dispositional approach to job attitudes: A lifetime longitudinal test. Administrative Science Quarterly, 31: 56-77.

Staw, B. M., \& Ross, J. 1985. Stability in the midst of change: A dispositional approach to job attitudes. Journal of Applied psychology, 70: 469-480.

Stephan, Y., Sutin, A. R., \& Terracciano, A. 2014. Physical activity and personality development across adulthood and old age: Evidence from two longitudinal studies. Journal of Research in Personality, 49: 1-7.

Stephan, Y., Sutin, A. R., \& Terracciano, A. 2015. How old do you feel? The role of age discrimination and biological aging in subjective age. PloS One, 10: e0119293.

Stewart, A. J., \& Deaux, K. 2012. Personality and social contexts as sources of change and continuity across the life span. In K. Deaux \& M. Snyder (Eds.), The Oxford handbook of personality and social psychology. London: Oxford University Press. 
Stewart, G. L., \& Barrick, M. R. 2004. Four lessons learned from the person-situation debate: A review and research agenda. In D. B. Smith \& B. Schneider (Eds.), Personality and organizations: 61-85. Mahwah, NJ: Lawrence Erlbaum Associates, Ltd.

Stoll, G., \& Trautwein, U. 2017. Vocational interests as personality traits: Characteristics, development, and significance in educational and organizational environments. In J. Specht (Ed.), Personality development across the lifespan: 401-417. London: Academic Press.

Swann, W. B., \& Read, S. J. 1981. Self-verification processes: How we sustain our selfconceptions. Journal of Experimental Social Psychology, 17: 351-372.

Tasselli, S., \& Kilduff, M. 2017. When brokerage between friendship cliques endangers trust: A personality-network fit perspective. Academy of Management Journal. In press

Tasselli, S., Kilduff, M., \& Menges, J. I. 2015. The microfoundations of organizational social networks: A review and an agenda for future research. Journal of Management, 41: 1361-1387.

Tett, R. P., \& Burnett, D. D. 2003. A personality trait-based interactionist model of job performance. Journal of Applied Psychology, 88: 500-517.

Thern, E., de Munter, J., Hemmingsson, T., \& Rasmussen, F. 2017. Long-term effects of youth unemployment on mental health: Does an economic crisis make a difference? Journal of Epidemiology and Community Health. In press.

Trice, H. M. 1962. The job behavior of problem drinkers. Society, culture and drinking patterns. New York: John Wiley and Sons.

Turnley, W. H., \& Bolino, M. C. 2001. Achieving desired images while avoiding undesired images: Exploring the role of self-monitoring in impression management. Journal of Applied Psychology, 86: 351-360.

Vedres, B., \& Stark, D. 2010. Structural folds: Generative disruption in overlapping groups. American Journal of Sociology, 115: 1150-1190.

Wagner, J., Lüdtke, O., Jonkmann, K., \& Trautwein, U. 2013. Cherish yourself: Longitudinal patterns and conditions of self-esteem change in the transition to young adulthood. Journal of Personality and Social Psychology, 104: 148-163.

Walker, B. M., \& Winter, D. A. 2007. The elaboration of personal construct psychology. Annual Review of Psychology, 58: 453-477.

Warner, W. L., \& Lunt, P. S. 1941. The social life of a modern community. New Haven, CT: Yale University Press.

Watson, D. 2002. Positive affectivity: The disposition to experience pleasurable emotional states. In C. R. Snyder, \& S. J. Lopez (Eds.), Handbook of positive psychology: 106-119. London: Oxford University Press.

Watson, D., \& Humrichouse, J. 2006. Personality development in emerging adulthood: Integrating evidence from self-ratings and spouse ratings. Journal of Personality and Social Psychology, 91: 959-974.

Webb, G., Shakeshaft, A., Sanson $\square$ Fisher, R., \& Havard, A. 2009. A systematic review of work $\square$ place interventions for alcohol $\square$ related problems. Addiction, 104: 365-377. 
Weiss, A., Bates, T. C., \& Luciano, M. 2008. Happiness is a personal (ity) thing: The genetics of personality and well-being in a representative sample. Psychological Science, 19: 205210.

West, M., Nicholson, N., \& Arnold, J. 1987. Identity changes as outcomes of work-role transitions. In T. Honess \& K. Yardley (Eds.), Self and identity: Perspectives across the lifespan: 287-303. New York: Routledge \& Kegan Paul.

Wiggins, J. S. 1991. Agency and communion as conceptual coordinates for the understanding and measurement of interpersonal behavior. In D. Cicchetti \& W. M. Grove (Eds.), Thinking clearly about psychology: Essays in honor of Paul E. Meehl (Vol. 1): 89-113. Minneapolis: University of Minnesota Press.

Wille, B., Beyers, W., \& De Fruyt, F. 2012. A transactional approach to person-environment fit: Reciprocal relations between personality development and career role growth across young to middle adulthood. Journal of Vocational Behavior, 81: 307-321.

Wille, B., \& De Fruyt, F. 2014. Vocations as a source of identity: Reciprocal relations between Big Five personality traits and RIASEC characteristics over 15 years. Journal of Applied Psychology, 99: 262-281.

Wilson, T. D. 2011. Redirect: The surprising new science of psychological change. New York: Little, Brown.

Winter, D. A., \& Reed, N. (Eds.). 2015. The Wiley handbook of personal construct psychology. Chichester, UK: John Wiley \& Sons.

Winter, D. G. 2011. Philosopher-king or polarizing politician? A personality profile of Barack Obama. Political Psychology, 32: 1059-1081.

Wu, C. H. 2016. Personality change via work: A job demand-control model of Big Five personality changes. Journal of Vocational Behavior, 92: 157-166.

Yeager, D. S., \& Dweck, C. S. 2012. Mindsets that promote resilience: When students believe that personal characteristics can be developed. Educational Psychologist, 47: 302-314.

Yeager, D. S., \& Walton, G. M. 2011. Social-psychological interventions in education: They're not magic. Review of Educational Research, 81: 267-301.

Youssef, C. M., \& Luthans, F. 2007. Positive organizational behavior in the workplace: The impact of hope, optimism, and resilience. Journal of Management, 33: 774-800.

Zaccaro, S. J. 2007. Trait-based perspectives of leadership. American Psychologist, 62: 6-16.

Zimmerman, R. D. 2008. Understanding the impact of personality traits on individuals' turnover decisions: A meta-analytic path model. Personnel Psychology, 61: 309-348.

Zimmermann, J., \& Neyer, F. J. 2013. Do we become a different person when hitting the road? Personality development of sojourners. Journal of Personality and Social Psychology, 105: 515-530.

Zuroff, D. C. 1986. Was Gordon Allport a trait theorist? Journal of Personality and Social Psychology, 51: 993-1000. 
Figure 1.

\section{A Model of Antecedents and Outcomes of Personality Change}

\section{Antecedents of Change}

Self-Development (e.g., self-affirmation, state or trait change, self-

actualization)

\section{Organizational Events} and Processes (e.g., employment and career, organizational pressures, interpersonal relationships)

\section{External Events and} Processes (e.g., domestic jolts, education, aging)

\section{Personality Change}

Traits (e.g., Big Five

traits, Goldberg, 1993)

\section{Needs}

(e.g., need for status, need for belonging, Hogan, 1982; see Hennecke \& Freund, 2017, for a review)

\section{Personal Constructs}

(e.g., Kelly, 1955), and

Stories (e.g., McLean, 2017), etc.

\section{Outcomes}

\section{Identity Change}

(i.e., change in how the individual perceives the self in terms of vocational preferences, career outcomes, job engagement, etc.)

\section{Reputation Change}

(i.e., change in how the individual is evaluated by others in terms of job performance, citizenship behaviors, leadership potential, etc.) 